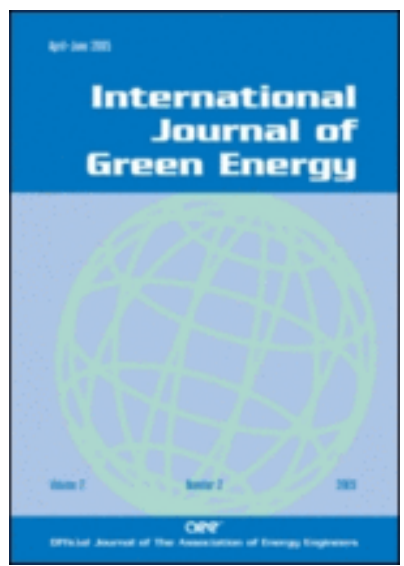

\title{
Overview of Recent Developments and the Future of Organic Rankine Cycle Applications for Exhaust Energy Recovery in Highway Truck Engines
}

\begin{tabular}{|r|l|}
\hline Journal: & International Journal of Green Energy \\
\hline Manuscript ID & IJGE-2020-0479 \\
\hline Manuscript Type: & Review Paper \\
\hline Author: & 11-Jun-2020 \\
\hline Complete List of Authors: & $\begin{array}{l}\text { Thaddaeus, Julius; Federal University Wukari, } \\
\text { Unachukwu, Godwin; University of Nigeria Faculty of Engineering, } \\
\text { Mechanical Engineering } \\
\text { Mgbemene, Chigbo; University of Nigeria Faculty of Engineering, } \\
\text { Mechanical Engineering } \\
\text { Pesyridis, Apostolos; Brunel University London } \\
\text { Mohammed, Ahmed; Brunel University London }\end{array}$ \\
\hline Keywords: & $\begin{array}{l}\text { Exhaust Heat Recovery, Organic Rankine Cycle Technology, Engine } \\
\text { Driving Profile, Daily Average Speeds, Recent Developments }\end{array}$ \\
\hline
\end{tabular}

\section{SCHOLARONE \\ Manuscripts}




\title{
Overview of Recent Developments and the Future of Organic Rankine Cycle Applications for Exhaust Energy Recovery in Highway Truck Engines
}

\author{
Thaddaeus Julius ${ }^{1}$ \\ Federal University Wukari - Nigeria \\ thaddeus.julius@fuwukari.edu.ng
}

Godwin Unachukwu ${ }^{\mathrm{a}}$ Chigbo Mgbemene ${ }^{\mathrm{a}}$ Ahmed Mohammed ${ }^{\mathrm{b}}$

Apostolos Pesyridis ${ }^{\mathrm{b}}$

${ }^{a}$ University of Nigeria, Nsukka - Nigeria

${ }^{\mathrm{b}}$ Brunel University London - UK

\begin{abstract}
Overall developments in internal combustion engines suggest that the ORC system recovers exhaust heat for further use, increases system performance, and decreases adverse environmental impacts, including greenhouse gas emissions, and particulate matter. This paper presents an overview of crucial advancements in the field of ORC application in commercial vehicles for WHR and continuing developments towards clean fuels and emission regulatory standards. The is review centred on the potential of ORC technology, its applications in highway truck engines heat recovery, and most notably, the bottlenecks associated with incorporating ORC technology into commercial vehicles exhaust energy recovery. Furthermore, a range of distinct engine operating patterns is reported in respect of average speeds of trucks to assess the appropriate operating points for the chosen application.
\end{abstract}

Keywords: Recent Developments, Exhaust Heat Recovery, ORC technology, Engine Driving Profile, Daily Average Speeds

$\begin{array}{ll}\text { Nomenclature } \\ \text { Abbreviations } \\ \text { BTE } & \text { brake thermal efficiency } \\ \text { CHP } & \text { combined heat and power } \\ \text { D } & \text { Dry Working Fluid } \\ \text { EHR } & \text { Exhaust Heat Recovery } \\ \text { GHG } & \text { Greenhouse gas } \\ \text { GWP } & \text { global warming potentials } \\ \text { I } & \text { Isentropic Working Fluid } \\ \text { ICE } & \text { internal combustion engine } \\ \text { M } & \text { Molar mass } \\ \text { NEDC } & \text { new European driving cycle } \\ \text { ODP } & \text { Ozone Layer Depletion } \\ \text { ORC } & \text { Potential } \\ \text { PM } & \text { organic Rankine cycle } \\ \text { R\&D } & \text { particulate matter } \\ \text { rpm } & \text { research and development } \\ \text { T-s } & \text { revolution per minute } \\ \text { W } & \text { temperature - entropy } \\ \text { WHR } & \text { Wet Working Fluid } \\ & \text { Waste heat recovery }\end{array}$

$\begin{array}{ll}\text { Greek symbols } \\ \dot{m}_{r} & \text { Mass flow rate }[\mathrm{kg} / \mathrm{s}] \\ \dot{W} & \text { work done }[\mathrm{kW}] \\ h & \text { Enthalpy }[\mathrm{kJ} / \mathrm{kg}] \\ h s & \text { Heat source } \\ \mathbf{n} & \text { Efficiency }[\%] \\ Q & \text { Thermal power }[\mathrm{kJ}] \\ \rho & \text { Density }\left[\mathrm{kg} / \mathrm{m}^{3}\right] \\ \omega & \text { Speed }[\mathrm{rad} / \mathrm{s}] \\ \text { Subscripts } & \\ \text { b } & \text { boiling } \\ \text { c } & \text { critical } \\ \text { in } & \text { Inlet } \\ \text { mech } & \text { Mechanical } \\ \text { out } & \text { Outlet } \\ t h & \text { Thermodynamic } \\ \text { turb } & \text { Turbine }\end{array}$




\section{Introduction}

Exhaust gases release from the transportation and industrial sectors have significant negative impacts on our environment and air quality. Studies indicate that the transport sector consumes much of the World's fuel, accounting for more than $67 \%$ of overall fuel consumption in the United States., [1] and 73\% in the United Kingdom in 2013, [2]. The transport industry contributes to air pollution through Nitrogen oxides (NOx) and PM emissions and to global warming through $\mathrm{CO}_{2}$ emissions. Due to the inefficiencies of ICEs, about 60 to $65 \%$ of the fuel that is supplied to the engine is released into the atmosphere in form of heat via the exhaust and cooling systems. This inefficient conversion of fuel energy to mechanical work results in a rise in entropy and causes severe negative environmental impacts; yet, technologies exist that can convert such energy in the waste heat to useful work, [3]. Today these concerns combined necessitate the development of more efficient combustion engine process as an effective way of deploying fuel sources to use. The energy in the exhaust gas could be converted to mechanical, then to electrical power for the vehicle by applying a suitable thermodynamic Rankine process (Organic Rankine Cycle).

In recent times, research and development interests are focusing on Organic Rankine Cycle Systems (ORC) as an exhaust heat recovery technology in automotive engines. The technology typically is deployed in small to modest temperature heat sources due to the low boiling point of organic fluids compare to steam which is used primarily in large scale applications. The Organic Rankine system generates mechanical energy which either delivers power directly via a belt or a gearbox to the engine shaft, or produces electricity employing an electric generator.

This study is an overview of recent developments in ORC technologies used for exhaust heat recovery in long-haul truck engines with the primary goal of improving the thermal performance of these engines, lower greenhouse gas emissions, and consequently, low systems operational costs.

\section{Commercial Truck Engines}

Human movement and the transportation of goods are necessities of the society today. In addition to achieving acceptance by users, any solution to these issues must follow sustainability requirements. Accordingly, approaches must adhere with requirements of safe operation, energy sustainability, environmental safety, and accessibility. Transportation infrastructure must develop with progress in powertrains and better fuel and energy options to address the above-mentioned fundamental needs of contemporary society. The need to increase 
energy conservation and to decrease fossil fuels dependence would lead to a more substantial use of clean energy. Advances in travel requirements and the movement of goods and services help to develop the transportation business environment, as more people are expected to travel and move goods from one location to the other and thus, need safe and efficient options.

Given the insights from industrial associates, ERTRAC's R\&D forecasts that more than $60 \%$ of new commercial vehicles in Europe will continue to be powered by ICEs up to 2040: vehicle technologies will include ICE, hybrids, extended configurations and clean energy resources. Equally, due to the need for energy density in the propulsion of larger vehicles, internal combustion engines are expected to control the trucks market for some time, [4].

Diesel Engine is among the most significant emitters of carbon dioxide because it is the commonly used combustion process for heavy-duty trucks and ships applications, and, for small, medium-sized, stationary power generating plants. New environmental pollution measures on heavy-duty sectors, such as EURO VI and Tier 4 final, concerning NOx and PM, are also becoming stricter every year. Therefore, considerations on more engine innovation and performance increase have been of critical interest recently and several changes have been studied and implemented.

\subsection{Truck Driving Profiles}

The fundamental step in designing exhaust heat reuse devices for possible integration to automobile vehicles in a quest to improve the overall system efficiency and consequently reduce the rate of environmental pollutions is the exploration of actual driving patterns of these vehicles. The driving profile will provide insights into the regular operating points of the system and thus, its design configuration and optimal optimization points. These are critical spots at which the vehicle mostly involves in during operating periods; hence, significant in the designing process. United States NRE Laboratory has reported some commercial vehicles data regarding these points,[5]. Figure 2.1 to Figure 2. report the daily driving profiles of these vehicles in histograms. 

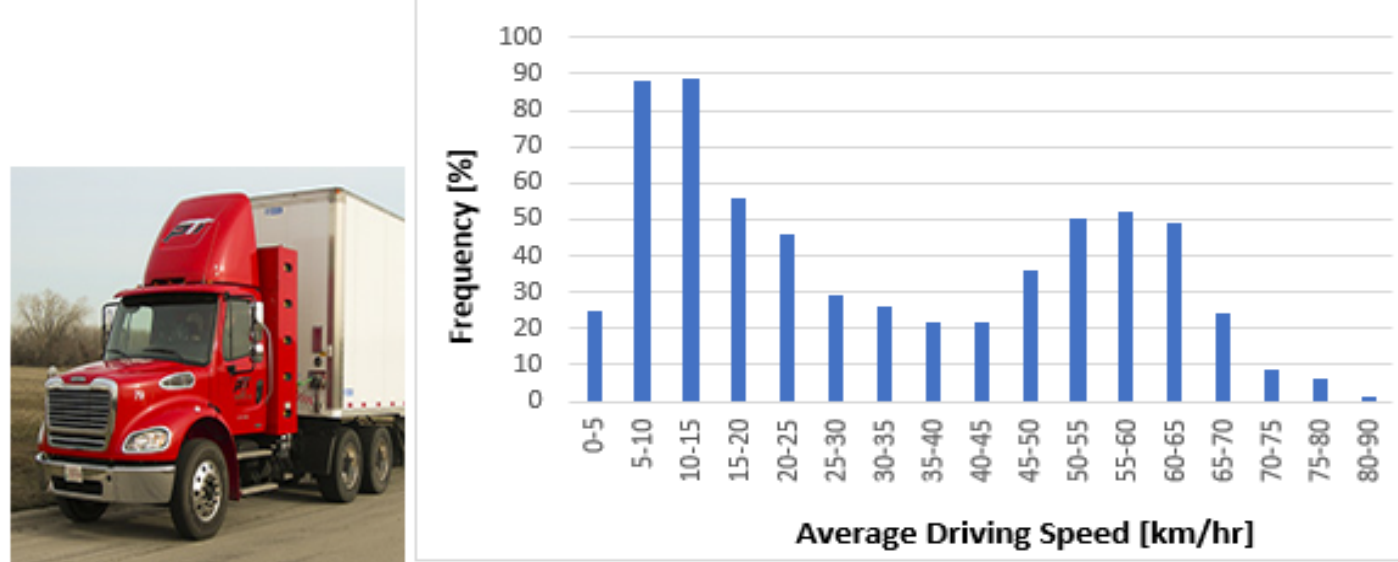

Figure 2.1. Highway Trucks Daily Average Driving Speed

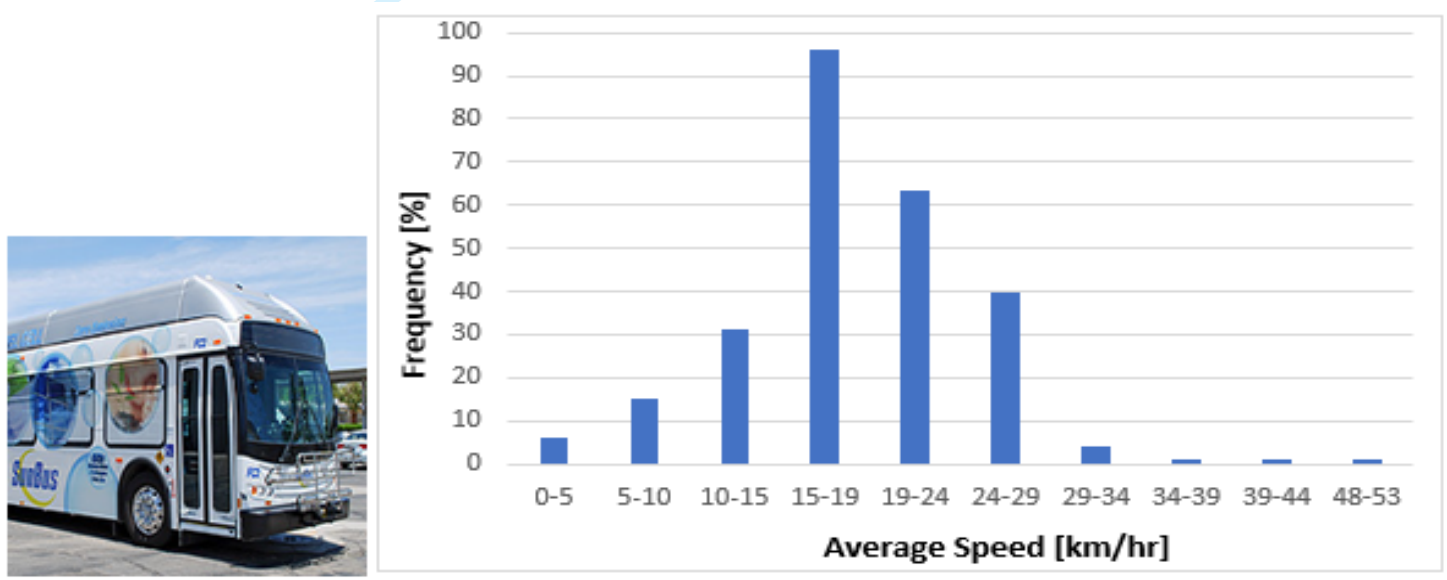

Figure 2.2. Buses Daily Average Driving Speed

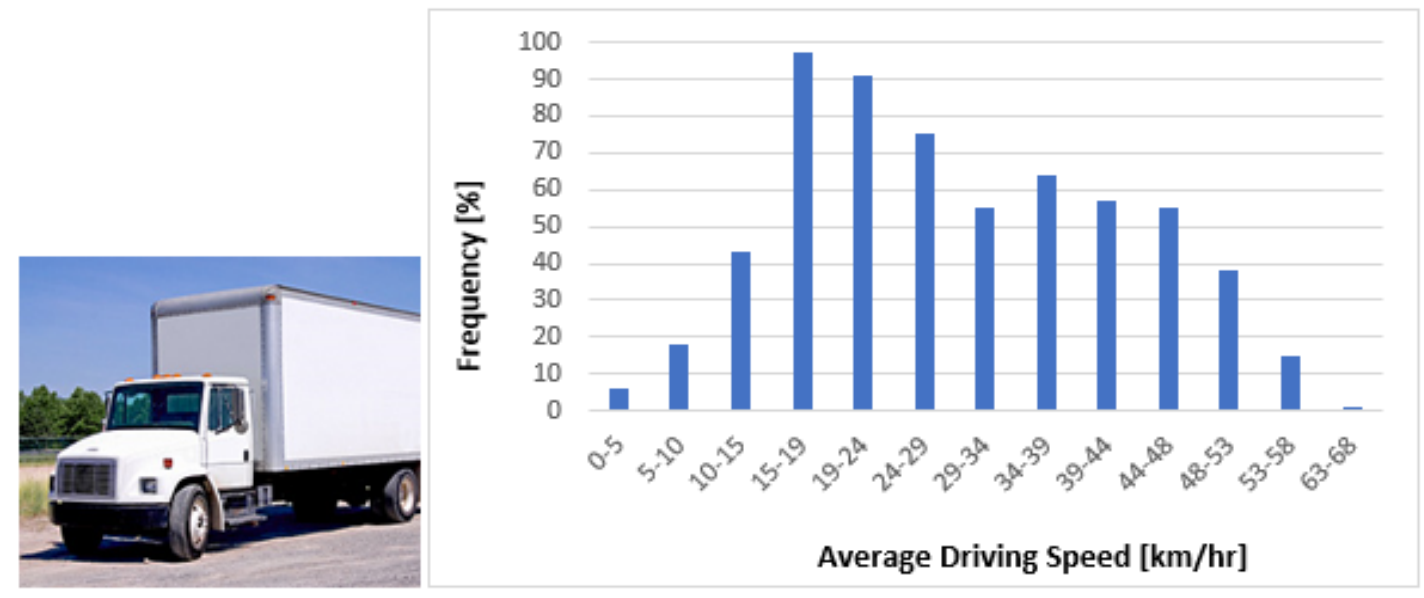

Figure 2.3. Delivery Trucks Daily Average Driving Speed 

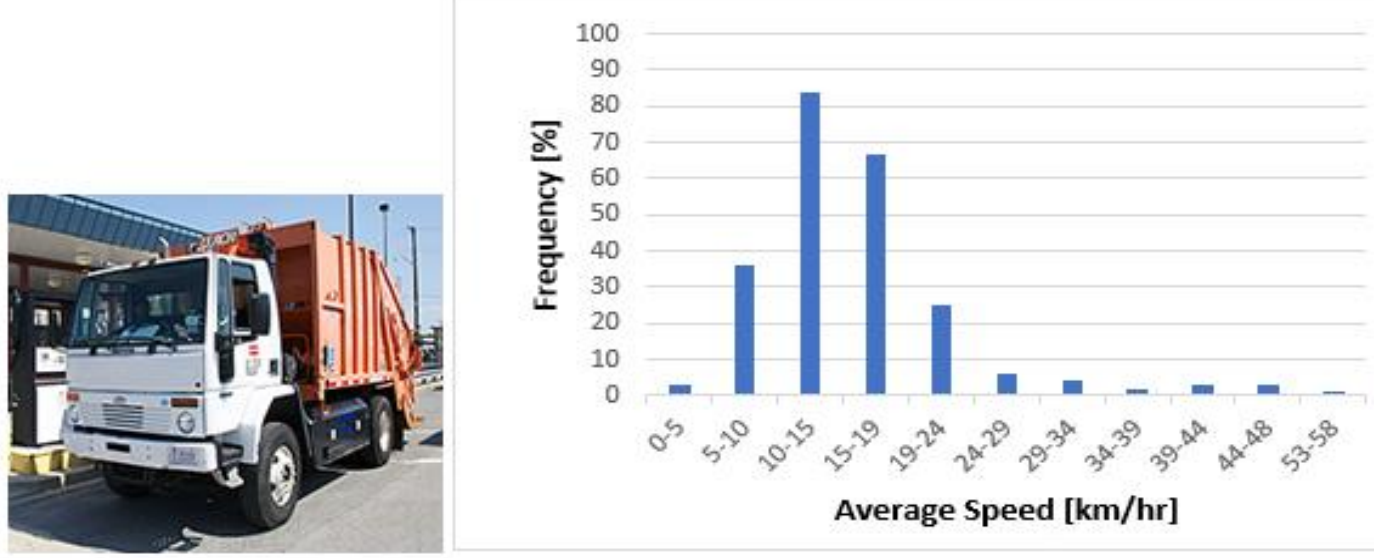

Figure 2.4. Refuse Trucks Daily Average Driving Speed

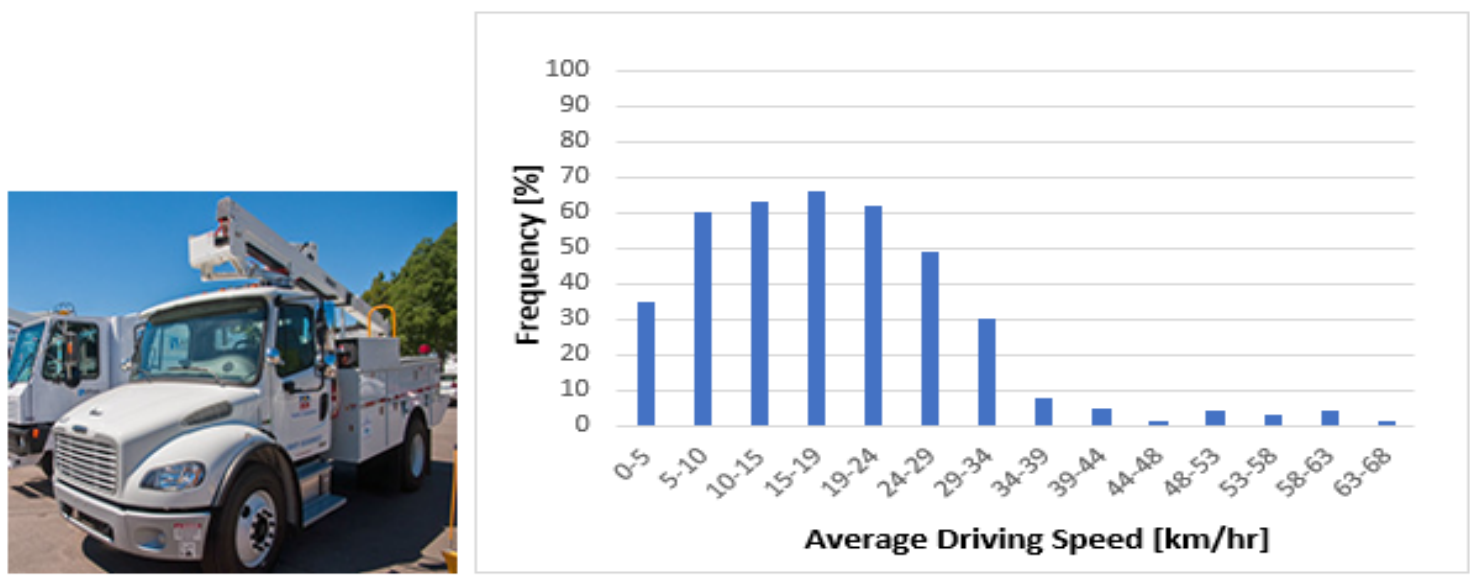

Figure 2.5. Bucket Truck Daily Average Driving Speed
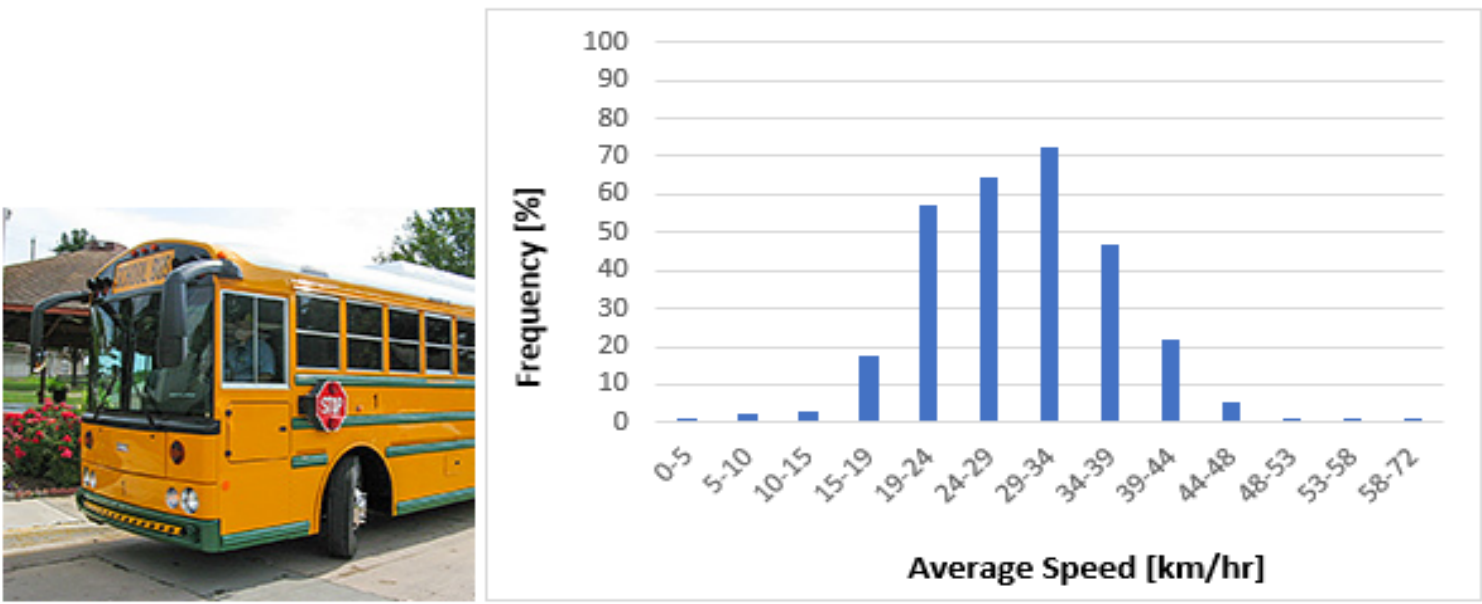

Figure 2.6. School Buses Daily Average Driving Speed 


\subsection{DE Sources of Heat}

In diesel engine combustion, approximately $40 \%$ of energy content in the fuel is lost to the environment via recoverable heat energies which includes exhaust gas, EGR, coolant, lubricant, and Charge Air Cooling (CAC) heats. They are categorised into two, with the first category being high-temperature heat sources: exhaust gas (470-870K), EGR (470-1030K), and the second class as low-temperature heat sources: coolant (350-380k), lubricants (350400K) and Charge Air Cooling (320-340),[6].

From different the different heat sources named above, the exhaust gas is the most promising candidate heat source for recovery. The mass flow and temperature of the EG are the major influencing factors of design process and performance of heat recovery systems. Most available reports on WHR are based on exhaust gas and EGR temperatures with minimal references to coolant, CAC, and lubricants heat recovery. The reason is based on the potential of high heat content in the exhaust gas and EGR for reuse. Exhaust heat has potentials of around $40 \%$ of the fuel heat energy content, thus, making its harvest an attractive investment in the transportation business. The possibilities of this exhaust gas harvest are dependent on its mass flow and temperature; hence, the higher their values, the greater the capacity of recovery.

\section{ORC Technology}

ORC system allows the use of low temperature $\left(<230^{\circ} \mathrm{C}\right)$, medium temperature $\left(230-650^{\circ} \mathrm{C}\right)$ and high temperature $\left(>650^{\circ} \mathrm{C}\right)$ for power generation, [7]. This technology is promising as it recovers heat from exhaust of internal combustion engines, which otherwise are normally released to the environment as waste heat. The cycle involves using a heat source to vaporize a pressurized organic fluid, then allowed it to expand in a turbine. The power output of the turbine is converted to electricity using a generator, [8]. In organic Rankine cycle-based heat recovery systems, the heat source is the waste heat produced by some primary combustion process. The primary sources of heat from internal combustion engines are exhaust gas. Individual heat sources can be exploited separately or in tandem if the situation permits, in which case the generated power augments the vehicle's propulsion system or drives a generator that produces electricity for the vehicle's electrical systems. The ORC is not just the focus of laboratory study but an industrial feasibility, with more than 100 ORC plants in operation. Examples of ORC plants installed across the globe include the Altheim geothermal project, the Admont, Lienz and Heidelberg biomass-fired CHP plants, to name just a few, [9]. 
Increasingly the threat of global warming and associated outcomes is compelling energy planners to focus on developing environmentally friendly energy conversion technologies that produce electricity with fewer emissions. The utilization of waste heat reduces thermal pollutions, mitigates greenhouse gas emissions while fostering energy conservation. The challenges with ORC however are low thermal performance, limited methods to increase work production, the option of working fluids (organic) that suit existing heat sources and sink temperatures and their impact on the environment, [8]. ORC is a power cycle which transforms heat to work with ORC fluids. A schematic diagram of a typical organic Rankine cycle that consists of four main components: evaporator, turbine, condenser, and pump is shown in Figure 3.1. As earlier mentioned, ORC is a Rankine cycle, and hence it applies the same operating principle. The liquid is pressurized in the pump (Process 1-2) and then heated and vaporized in the evaporator (by the incoming exhaust gas from the engine in a counter current flow), which causes the fluid to change its state from liquid to vapour (Process 2-3). The now hightemperature, high-pressure vapour is then expanded in the turbine, which extracts energy from the superheated working fluid for mechanical power (Process 3-4). Finally, the vapour upon leaving the expander condenses back to liquid in the condenser (Process 4-1), and the cycle repeats.

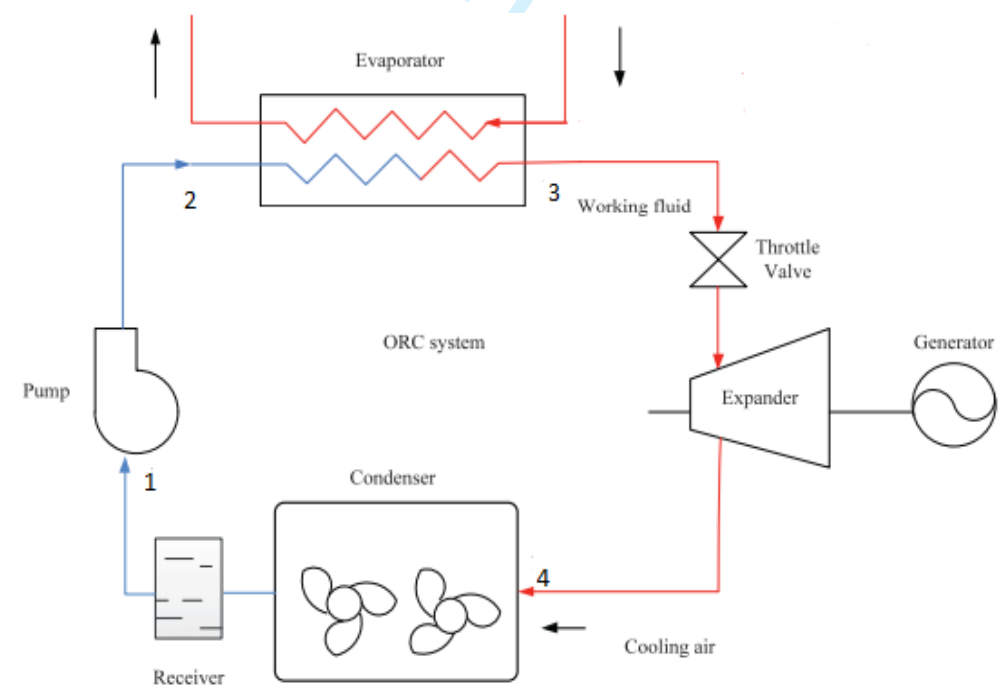

Figure 3.1. Schematic diagram of an ORC system, [10]. 


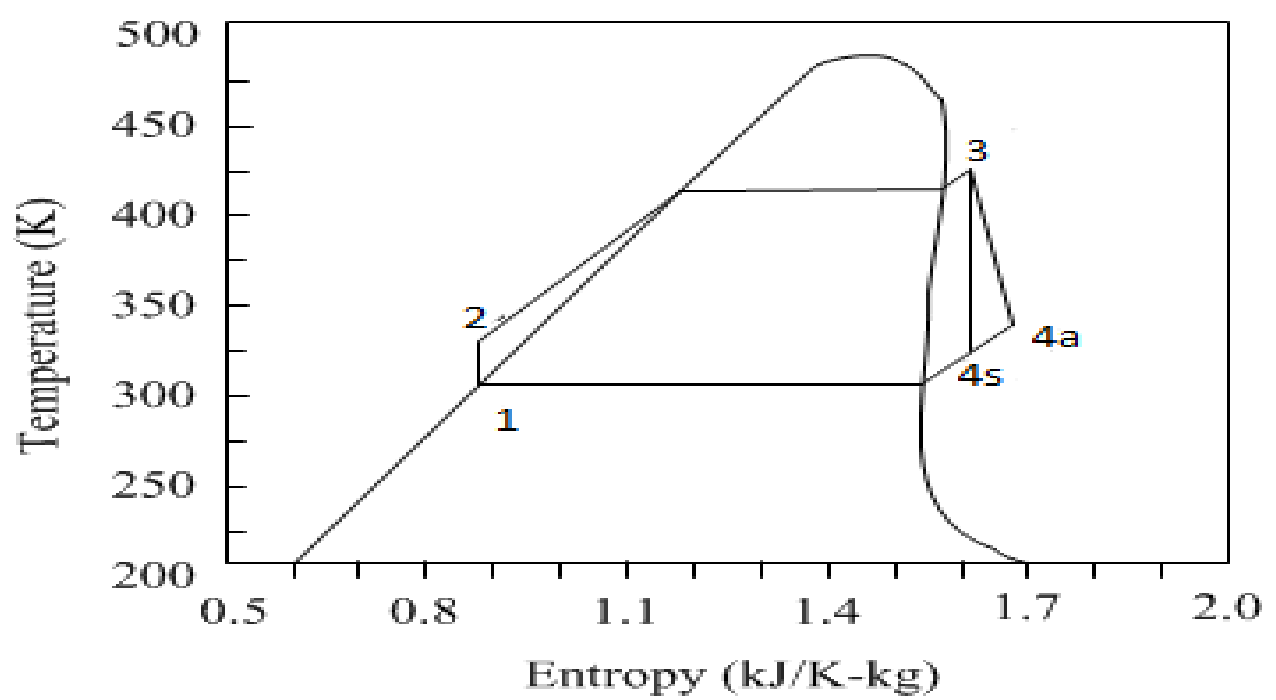

Figure 3.2. R-245fa T-s Diagram, [10].

While the theoretical Rankine cycle is based on a sequence of reversible processes, real-world systems involve irreversible changes in pump and expansion equipment. Thus, real cycles do not involve any isentropic changes of state. The efficiency of the ORC unit, however, depends on the system working fluids, evaporators, expanders, pumps, or condensers. It considers that it is the most effective process for recovering waste heat from low temperatures, [11].

The thermal efficiency $\eta_{t h}$ of a ORC system can be calculated by considering its network output $W_{\text {net }}$ and the heat input $Q_{\text {in }}$ (which is supplied during stage 1-2), equation (2.1).

The network output is calculated by subtracting the and pumping consumption, $W_{\text {pump }}$ from the mechanical output of the expansion device $W_{\text {mech }}$

$$
\eta_{t h}=\frac{W_{n e t}}{Q_{\text {in }}}=\frac{W_{\text {mech }}-W_{\text {pump }}}{Q_{\text {in }}} \ldots \ldots \ldots \ldots \ldots \ldots \ldots \ldots \ldots \ldots \ldots \ldots \ldots \ldots \ldots \ldots \ldots \ldots \ldots
$$

\subsection{ORC Process Designs for HD Trucks}

In truck installations, the ORC module is always deployed downstream of catalytic devices to prevent effects that will negate the emission control process. For possible implementation of heat recovery systems in automobiles, the architect should remain as simple as possible and take advantage of constituents that already exist in the truck design to alleviate installation costs, intricacy, and weight. Most used heat recovery system architectures for implementation in trucks are as follows: 


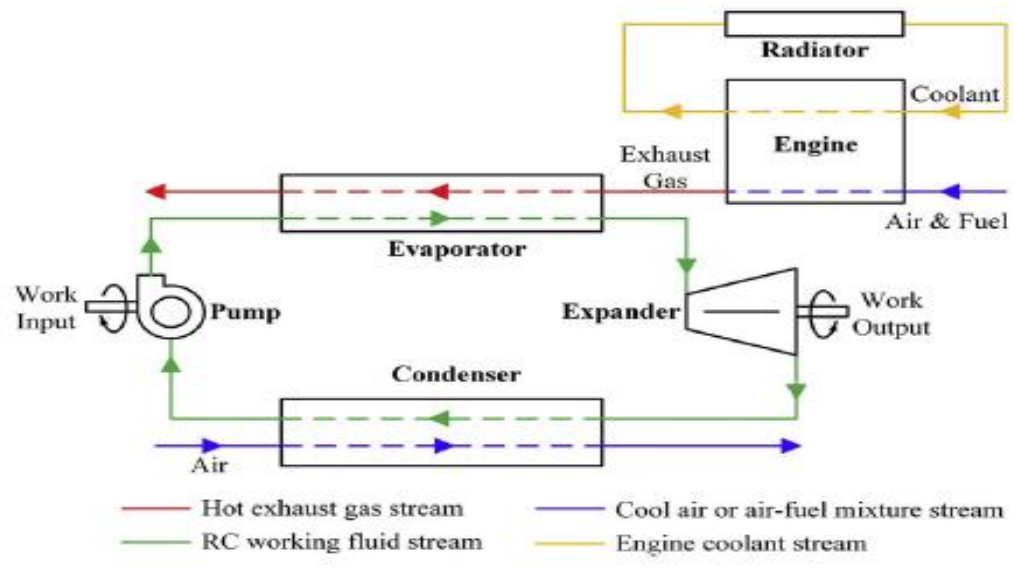

Figure 3.3. Simple ORC Design Layout

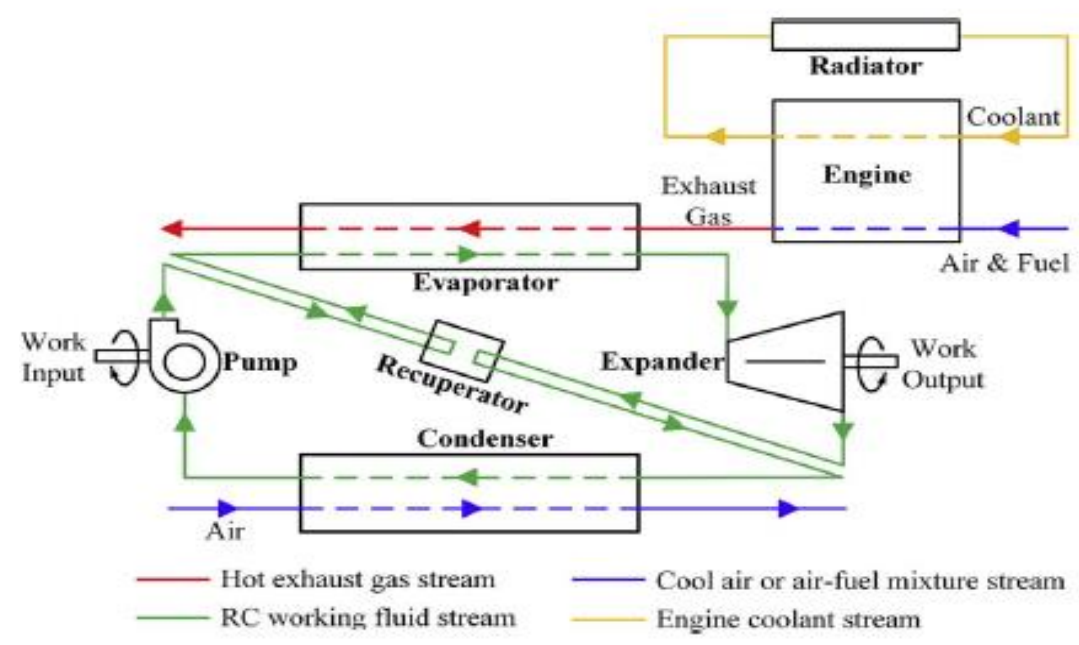

Figure 3.4. ORC Layout with Recuperate

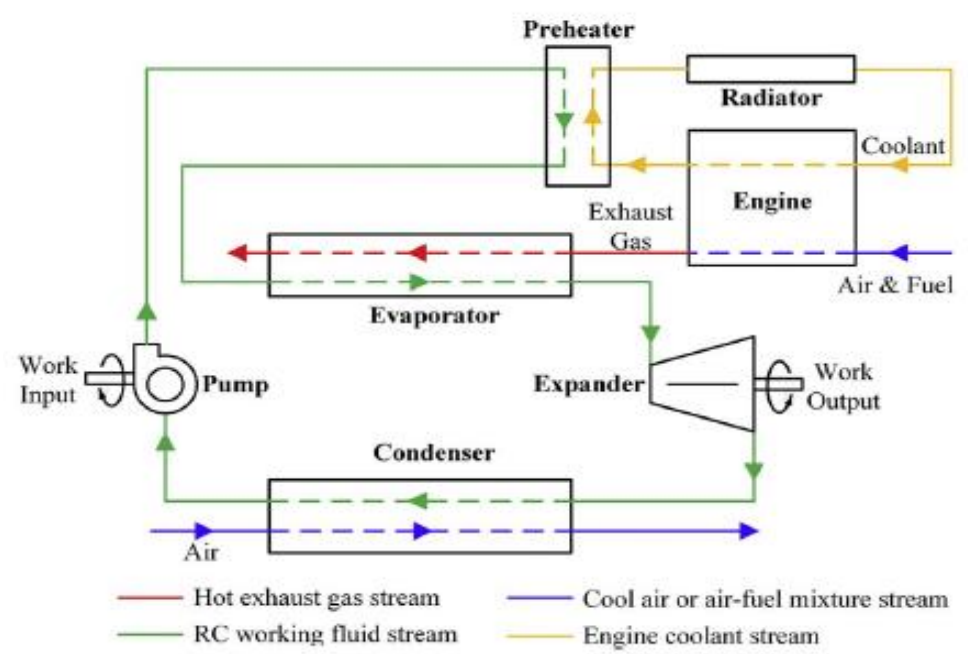

Figure 3.5. ORC Model with Preheater 


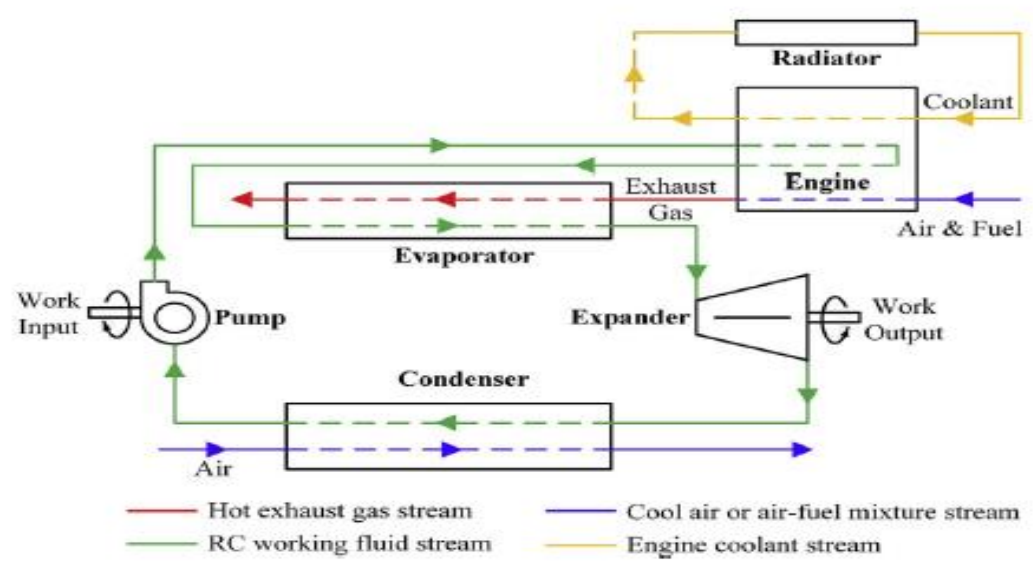

Figure 3.6. ORC Layout with Engine Block Preheater

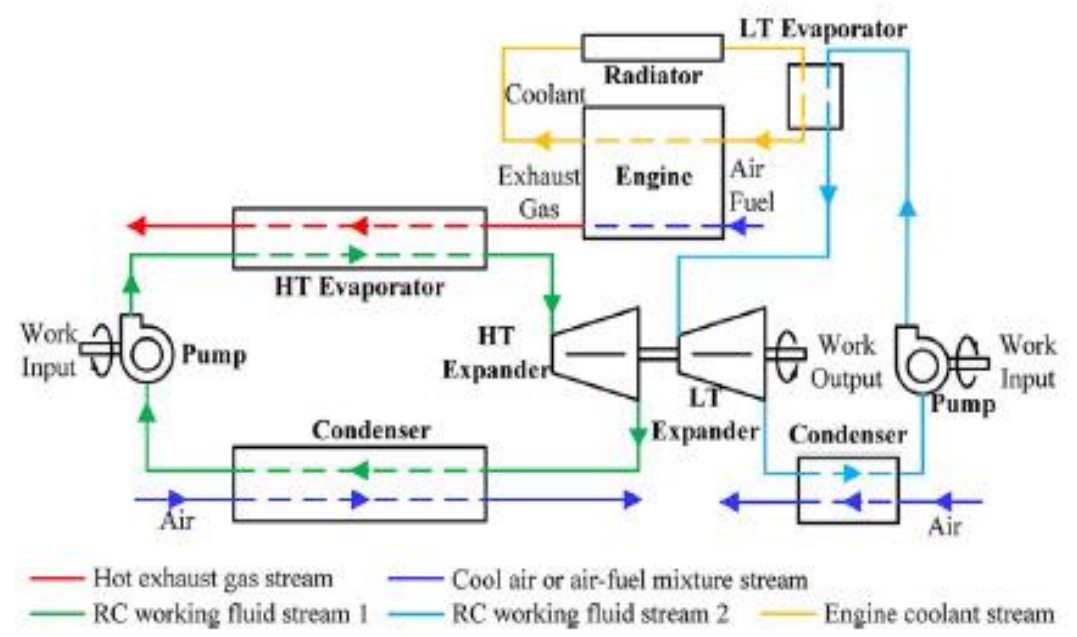

Figure 3.7. Layout with Dual Loops

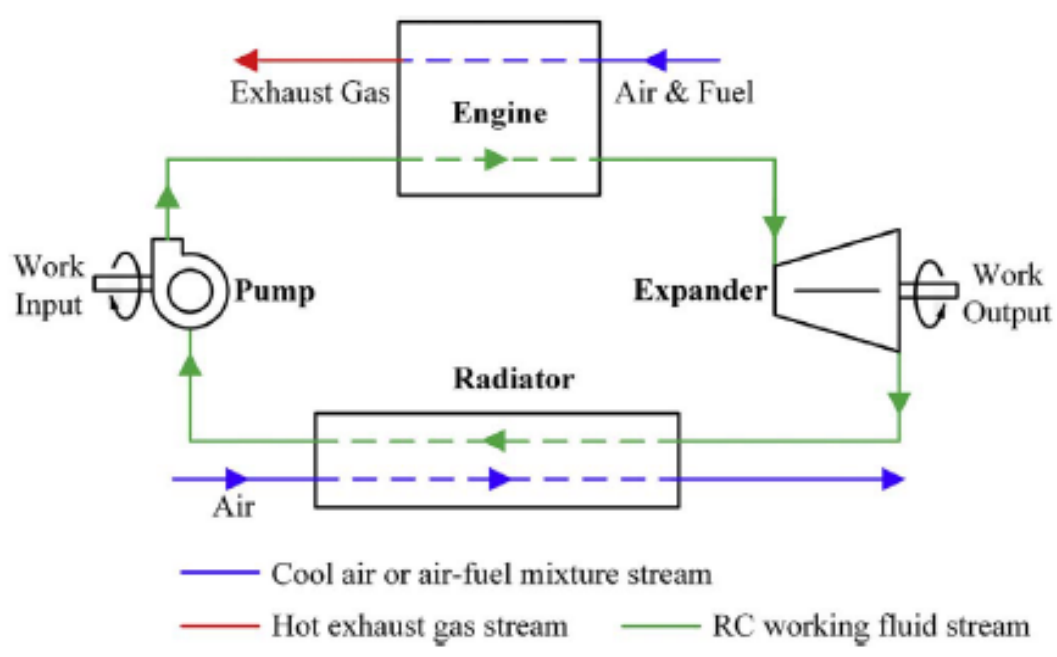

Figure 3.8. ORC Layout with Evaporative Engine Cooling System 
Figure 3.3 presents the first layout, which is simple and most common used ORC layout for truck applications. Exhaust gas is the only heat source that vaporises the organic fluid, and the design consists only of the pump, evaporator, expander and air condenser. Heat rejection from the system is via the radiator. Figure 3.4 represents an ORC architect with a recuperate for preheating the organic fluid before entering the evaporator heat exchanger with the vapour exiting the expander. This concept enhances the performance of the energy recovery unit with reduced heat input. In Figure 3.5, the ORC structure has preheater as an additional component which preheats the working fluid with heat from engine coolant. This module is like that of structure 2, where the preheating process is achieved by the vapour exiting the expander, thereby reducing the condenser cooling load. Few studies outline the advantages of energy recovery from exhausts and engine coolant simultaneously. A 10-35\% of increased ORC net power achieved in heat recovery from EG and engine coolant as compare to the layout with only exhaust heat as Vaja and Agostino reported a heat source, (2010), [12]. Also, a 1.8\% increase in engine bsfc was accomplished with a concept of exhaust and coolant heat recovery relative to the design with only exhaust gas as the heat sources, [13].

The heat recovery system layouts continue with Figure 3.6 representing an ORC design with engine block partially vaporising the working fluid. In this case, the working fluid should not be allowed to vaporise completely, thus enter the evaporator as a two-phase vapour, [14]. Figure 3.7 is a concept with dual loops mostly suitable for highway HD truck applications. The design uses water in HT loop and ethanol in LT loop, respectively. It has the advantage of making use of the possibilities of energy recovery in the system at the detriment of more complex module, [15]. In Figure 3.8, the architect adopts the engine cooling unit as an evaporator heat exchanger and the radiator as condenser. The structure has expander as the only added components to the whole module, though, the design requires moderation of the engine cooling device,[16].

\subsection{ORC Working Fluids for Truck Engine Applications}

Choosing the appropriate WF for Rankine cycle application is an essential step in heat recovery system designs. The approach depends on several essential requirements for such candidate fluid to have. These requirements include non-flammable, non-corrosive, non-toxic, zero ODP (ozone layer depletion potential), small global warming potential (GWP), high decomposition temperature, compatible with the system material and lubricant, excellent properties such as 
low freezing point, high vapour pressure, small viscosity, appropriate critical points, available, stable and low cost,[17][18].

Three types of working fluids exist for ICEs heat recovery Rankine cycle systems. These include wet, dry, and isentropic fluids, Figure 3.9. A negative gradient characterises the wet type fluids in t-s diagrams, and examples of wet fluids are water and ammonia. These fluids require a minimum amount of superheat at the expansion machine inlet to prevent droplets formation on the turbine blade during the expansion process, which causes cavitation effect and surface damage. High degree of superheat would consequently reduce the overall system performance and compromise the life cycle of the expansion machine material. The appropriate practice when using wet fluid is to maintain dryness fraction of above $85 \%$ without having excessive superheat,[19]. The application of the wet fluid requires frequent servicing and revamp of the turbines. Positive t-s diagrams define dry working fluids, and examples include R113, R123 and R245ca, to name a few. Dry fluids do not require to superheat in during expansion. If applied, a more considerable amount of superheat results at the outlet of the expansion machine thereby demanding a more significant amount of cooling load to bring the working fluid temperature down to sub-cooled state, thus, reduce the overall efficiency of the WHR unit. While, isentropic fluids are characterised by close-to-vertical line type of t-s diagrams, and an example is R245fa, [20]. Isentropic fluids allow expansion process to take place along the vertical line of the t-s diagram without condensation, thus, making these fluids more superior to dry fluids in ORC applications since they are not excessively superheated at the exit of expansion machines. This criterion reduces the cooling load requirement by the condenser as compared to dry working fluids.

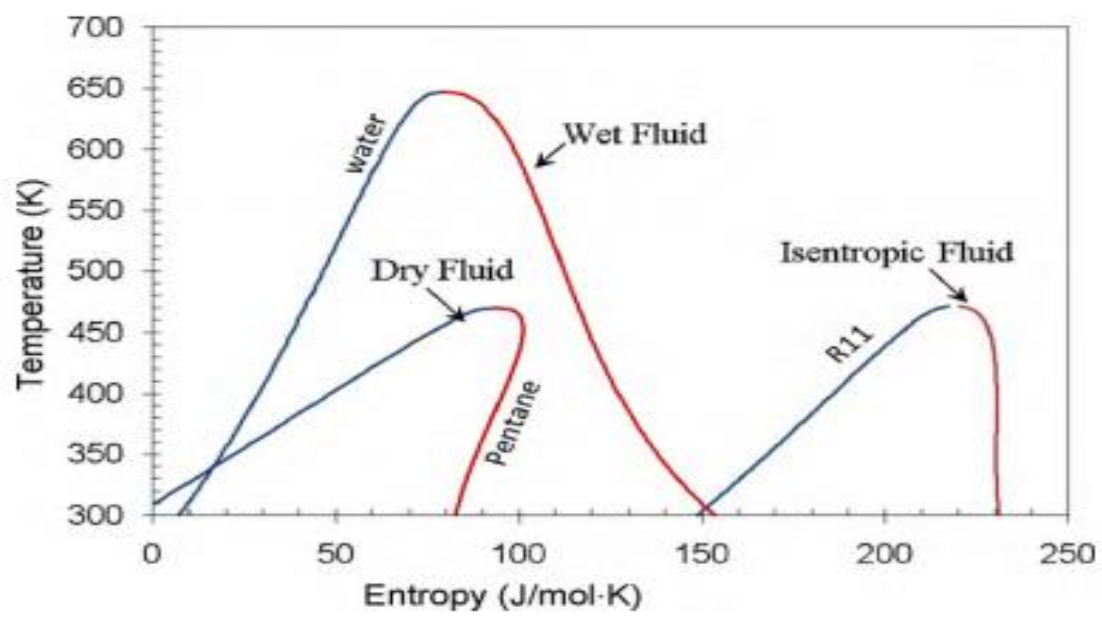

Figure 3.9. Example of the three working fluids type: wet, dry, and isentropic 
Organic working fluids are also categorised into two classes based on compositions as follows:

I. Pure Fluids: This class of working fluids include HFCs, HCFCs, PFCs, HCs, HFOs, CFCs, and HFEs. They have the potentials of application in ICE heat recovery modules.

II. Zeotropic Mixtures: These are working fluid mixtures with constituents having different boiling points. Examples of the components are benzene, ethanol, toluene, and isobutane. The different boiling points criterion makes the mixture composition not to vaporised or condense simultaneously, thus making them superior over pure fluids in low-grade heat recovery.

The ORC system design in this study is for truck engine application; as such, the selection criterion would focus on properties that concern automobile applications. For selection processes based on safety and environmental concerns, NPFA 704 standards are considered,[21]. Characterising based on health, flammability and chemical reactivity, the working fluids are scaled from 1 to 4 for low to high hazards, respectively,[22]. Some selection working fluids are classified in the Table 3.1 .

Table 3.1. ICE ORC Working Fluids Classification, [23][24]

\begin{tabular}{|c|c|c|c|c|c|c|c|c|c|c|}
\hline W. Fluid & C.F & Group & Type & $\begin{array}{l}\text { M. kg/ } \\
\text { kmole }\end{array}$ & $T_{c}, K$ & $T_{b}, K$ & $\begin{array}{l}\mathrm{Pc}_{\mathrm{c}} \\
\mathrm{MPa}\end{array}$ & ODP & GWP & S. L \\
\hline R11 & $\mathrm{CCl}_{3} \mathrm{~F}$ & CFC & I & 137.37 & 470.96 & 296.7 & 4.407 & 1 & 4750 & $\mathrm{~A} 1$ \\
\hline R12 & $\mathrm{CCl}_{2} \mathrm{~F}_{2}$ & CFC & W & 120.91 & 385.00 & 243.2 & 4.140 & 0.82 & 10,900 & $\mathrm{~A} 1$ \\
\hline R114 & $\mathrm{C}_{2} \mathrm{Cl}_{2} \mathrm{~F}_{4}$ & CFC & $\mathrm{D}$ & 170.92 & 427.70 & 276.6 & 3.257 & 0.58 & 9180 & $\mathrm{~A} 1$ \\
\hline R218 & $\mathrm{C}_{3} \mathrm{~F}_{8}$ & PFC & 1 & 188.02 & 344.95 & 248.7 & 2.671 & 0 & 8830 & $\mathrm{~A} 1$ \\
\hline RC318 & $\mathrm{C}_{4} \mathrm{~F}_{8}$ & PFC & $\mathrm{D}$ & 200.03 & 388.20 & 267.0 & 2.780 & 0 & 10,300 & $\mathrm{~A} 1$ \\
\hline R236fa & $\mathrm{C}_{3} \mathrm{H}_{3} \mathrm{~F}_{6}$ & HFC & $D$ & 152.04 & 397.90 & 271.6 & 3.200 & 0 & 9820 & $\mathrm{~A} 1$ \\
\hline R152a & $\mathrm{C}_{2} \mathrm{H}_{4} \mathrm{~F}_{2}$ & HFC & W & 66.05 & 386.26 & 259.0 & 4.517 & 0 & 140 & $\mathrm{~A} 2$ \\
\hline R227ea & $\mathrm{C}_{3} \mathrm{HF}_{7}$ & HFC & $D$ & 170.03 & 374.80 & 256.7 & 2.930 & 0 & 3580 & $\mathrm{~A} 1$ \\
\hline R134a & $\mathrm{C}_{2} \mathrm{H}_{2} \mathrm{~F}_{4}$ & $\mathrm{HFC}$ & I & 102.03 & 374.00 & 247.0 & 4.059 & 0 & 1300 & $\mathrm{~A} 1$ \\
\hline R245fa & $\mathrm{C}_{3} \mathrm{~F}_{5} \mathrm{H}_{3}$ & HFC & 1 & 134.05 & 427.00 & 288.1 & 3.651 & 0 & 1050 & $\mathrm{~B} 1$ \\
\hline R21 & $\mathrm{CHCl}_{2} \mathrm{~F}$ & HCFC & W & 102.92 & 451.33 & 281.8 & 5.181 & 0.04 & 151 & B1 \\
\hline R141b & $\mathrm{C}_{2} \mathrm{H}_{3} \mathrm{Cl}_{2} \mathrm{~F}$ & HCFC & 1 & 116.95 & 479.96 & 305.2 & 4.460 & 0.086 & 700 & - \\
\hline R123 & $\mathrm{C}_{2} \mathrm{HCl}_{2} \mathrm{~F}_{3}$ & HCFC & 1 & 152.93 & 456.83 & 301.0 & 3.662 & 0.012 & 120 & - \\
\hline R22 & $\mathrm{CHClF}_{2}$ & HCFC & W & 86.47 & 369.10 & 232.2 & 4.990 & 0.04 & 1790 & $\mathrm{~A} 1$ \\
\hline $\mathrm{R} 142 \mathrm{~b}$ & $\mathrm{CH}_{3} \mathrm{ClF}_{2}$ & HCFC & I & 100.50 & 410.10 & 263.9 & 4.060 & 0.06 & 2220 & $\mathrm{~A} 2$ \\
\hline
\end{tabular}




\begin{tabular}{|lllllllllll|}
\hline R124 & $\mathrm{C}_{2} \mathrm{HClF}_{4}$ & $\mathrm{HCFC}$ & $\mathrm{D}$ & 136.48 & 395.30 & 261.0 & 3.062 & 0.02 & 619 & $\mathrm{~A} 1$ \\
\hline R1234yf & $\mathrm{C}_{3} \mathrm{H}_{2} \mathrm{~F}_{4}$ & $\mathrm{HFO}$ & $\mathrm{I}$ & 114.04 & 367.70 & 243.5 & 3.380 & 0 & 4.4 & A2L \\
\hline R1234ze & $\mathrm{C}_{3} \mathrm{H}_{2} \mathrm{~F}_{4}$ & $\mathrm{HFO}$ & $\mathrm{I}$ & 114.04 & 382.40 & 253.4 & 3.630 & 0 & 6 & $\mathrm{~A} 2 \mathrm{~L}$ \\
\hline $\mathrm{HFE7000}$ & $\mathrm{C}_{4} \mathrm{H}_{3} \mathrm{~F}_{7} \mathrm{O}$ & $\mathrm{HFE}$ & $\mathrm{D}$ & 200.05 & 164.60 & 307.9 & 2.480 & 0 & 575 & - \\
\hline HFE7100 & $\mathrm{C}_{5} \mathrm{H}_{3} \mathrm{~F}_{9} \mathrm{O}$ & $\mathrm{HFE}$ & $\mathrm{D}$ & 250.00 & 195.30 & 332.6 & 2.230 & 0 & 297 & - \\
\hline HFE7500 & $\mathrm{C}_{9} \mathrm{H}_{5} \mathrm{~F}_{15} \mathrm{O}$ & $\mathrm{HFE}$ & $\mathrm{D}$ & 414.11 & 261.00 & 400.9 & 1.550 & 0 & - & - \\
\hline Propane & $\mathrm{C}_{3} \mathrm{H}_{8}$ & $\mathrm{HC}$ & $\mathrm{W}$ & 41.1 & 369.74 & 230.9 & 4.251 & 0 & 3.3 & $\mathrm{~A} 3$ \\
\hline Butane & $\mathrm{C}_{4} \mathrm{H}_{10}$ & $\mathrm{HC}$ & $\mathrm{D}$ & 58.12 & 425.00 & 272.1 & 3.800 & 0 & 3 & $\mathrm{~A} 3$ \\
\hline Pentane & $\mathrm{C}_{5} \mathrm{H}_{12}$ & $\mathrm{HC}$ & $\mathrm{D}$ & 72.15 & 469.50 & 308.5 & 3.360 & 0 & 4 & - \\
\hline Hexane & $\mathrm{C}_{6} \mathrm{H}_{14}$ & $\mathrm{HC}$ & $\mathrm{D}$ & 86.18 & 507.70 & 241.8 & 3.060 & - & - & - \\
\hline Heptane & $\mathrm{C}_{7} \mathrm{H}_{16}$ & $\mathrm{HC}$ & $\mathrm{D}$ & 100.21 & 540.00 & 370.9 & 2.730 & - & 0 & - \\
\hline Octane & $\mathrm{C}_{8} \mathrm{H}_{18}$ & $\mathrm{HC}$ & $\mathrm{D}$ & 114.23 & 569.20 & 398.0 & 2.500 & - & - & - \\
\hline Propylene & $\mathrm{C}_{3} \mathrm{H}_{6}$ & $\mathrm{HC}$ & $\mathrm{W}$ & 42.08 & 365.40 & 225.0 & 4.660 & - & 2 & A3 \\
\hline Benzene & $\mathrm{C}_{6} \mathrm{H}_{6}$ & $\mathrm{HC}$ & $\mathrm{D}$ & 78.11 & 561.87 & 353.1 & 4.907 & - & - & - \\
\hline Toluene & $\mathrm{C}_{7} \mathrm{H}_{8}$ & $\mathrm{HC}$ & $\mathrm{D}$ & 92.14 & 591.60 & 383.6 & 4.126 & - & 2.7 & - \\
\hline
\end{tabular}

Some reported studies on choosing the appropriate working fluid for heat recovery in ICEs are consulted. Wang et al. (2017) studied on the response performance of R245fa, R141b, Cyclohexane, and Toluene working fluids ICEs applications,[25]. In another study, R245fa, R141b, and R123 demonstrated high thermal performance of 21 screened organic fluids for exhaust energy recovery in IC engines,[26]. In the same vein, the screening of 31 working fluids was conducted to assess their performance in low-grade heat organic Rankine cycle systems,[27].

Despite the number of studies on selecting working fluid for ICE ORC systems, no single fluid can be defined as the most appropriate for all ORC applications. The selection process depends heavily on the field of usage, power scale, heat source and heat sink temperature. The goal is to select different optimum fluids based on the maximisation of the cycle power generation, environmental considerations, or economics.

\subsection{ORC Applications}

The typical advantage of the ORC over the steam (Rankine) cycle is its ability to transform low-heat sources into mechanical power more effectively. This technology opens a broad array of possibilities that would not have been possible with the steam cycle with higher boiling 
point. A general overview of the various possible uses of ORC technology is provided with focus on small to medium-scale in biomass / CHP, geothermal, ocean-thermal and waste heat recovery, [28].

\subsubsection{Application in Automobiles}

In the transport sector, the exhaust heat recovery device transforms exhaust thermal losses into power. This exhaust reuse technology is up-and-coming for light and heavy-duty vehicle manufacturers as an optimal way to save fuel and reduce $\mathrm{CO}_{2}$ emissions. Automotive engineers are increasingly looking at ways to make fuel-efficient vehicles amidst rising global air pollution. The technology recycles the exhaust before they leave the vehicle, which also helps to reduce emissions from the vehicle. The primary source of greenhouse gases release in the United States is $\mathrm{CO}_{2}$ emission from fossil fuel for power generation and transportation, (Figure 3.10).

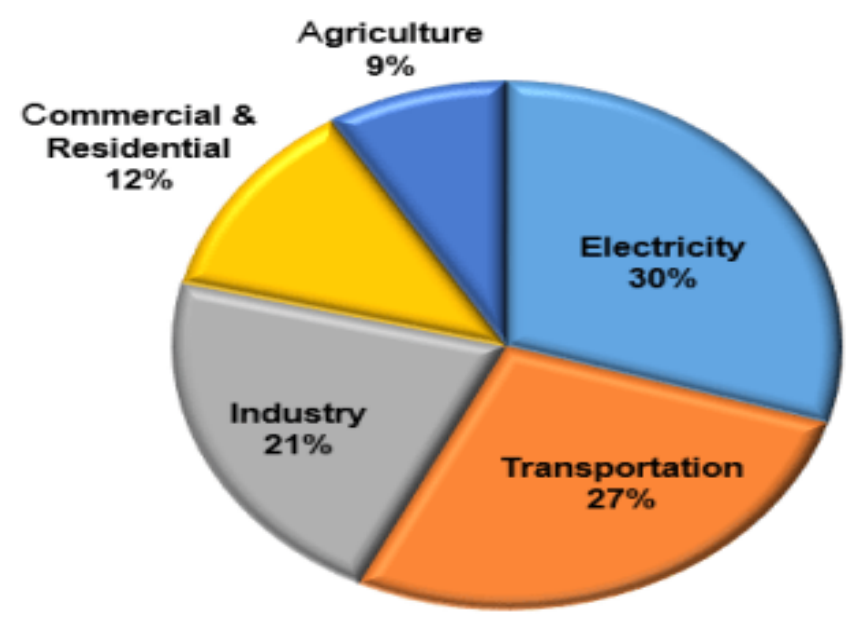

Figure 3.10. GHG Emissions by Sector [29]

BMW's turbosteamer was reported as the first demonstration prototype system in 2005 to use the application of the RC system for WHR from the exhaust gas to increase the thermal performance of the automobile combustion process. The cogeneration concept reduced fuel consumption in stationary operating conditions of the 4-cylinder SI engine by $10 \%$ at high-way speed, [30]. In 2012, the second-generation turbosteamer of BMW was reported to have been further simplified to ensure effective vehicle integration of the RC system for WHR, [31]. 


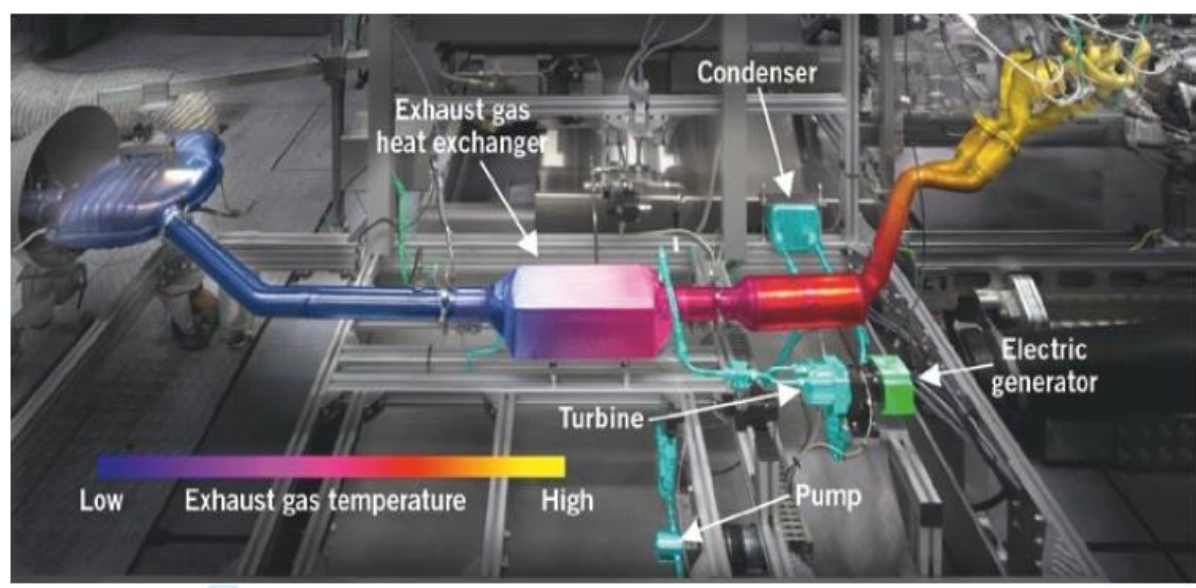

Figure 3.11. Turbosteamer Mounted on Test Rig, [31].

In 2005, Cummins undertook a concept of WHR for Class 8 truck which was funded by U.S Department of Energy. The project demonstrated an initial promising result, [32]. In 2013, Cummins again announced a milestone achievement in the WHR project of 50\% improvement in thermal brake efficiency (BTE) and consequent increase in fuel savings of $\sim 6 \%$, [33].

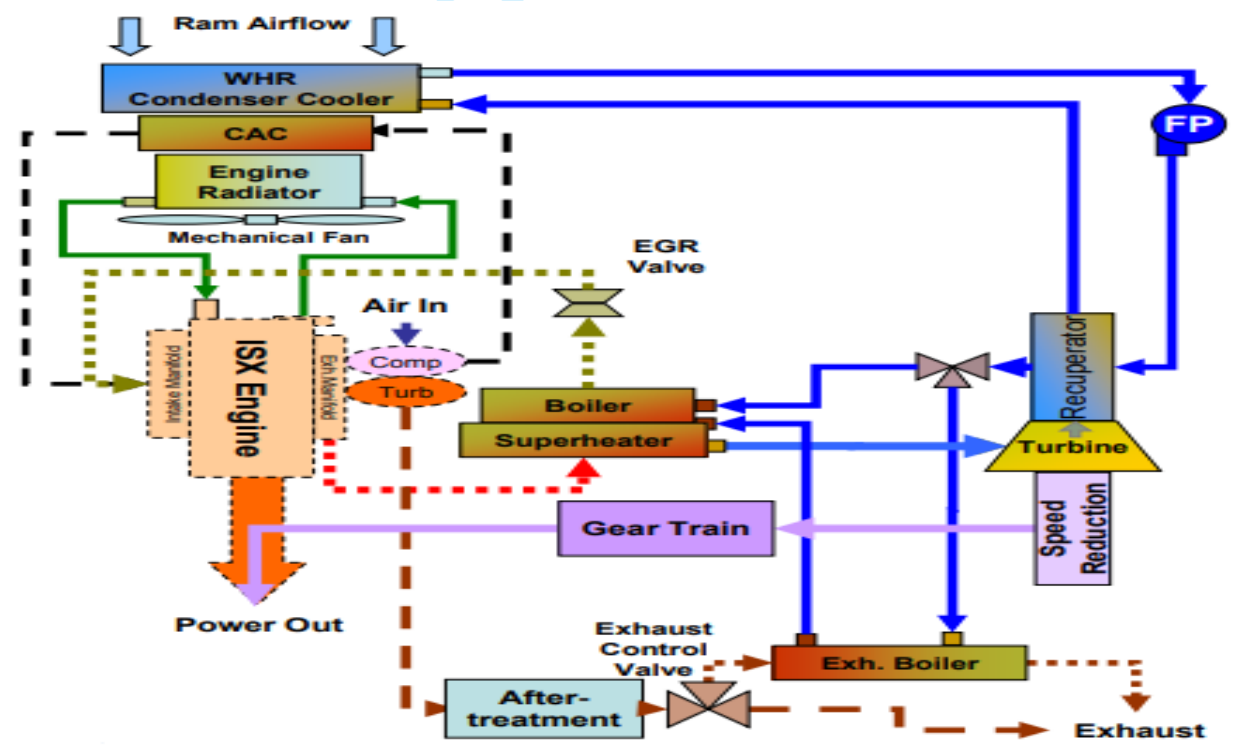

Figure 3.12. Cummins WHR Layout, [33]

In 2008, Honda reported a prototype Rankine cycle system installed in a hybrid vehicle for possible WHR from the engine (see Figure 3.13). Testing the vehicle at $100 \mathrm{~km} / \mathrm{h}$ constant speed resulted in a $13.2 \%$ increase in thermal efficiency. The newly designed cylinder head structure integrated with the evaporator generated a high-temperature steam with a heat quantity of $400^{\circ} \mathrm{C}, 8 \mathrm{MPa}$, and $14.3 \mathrm{~kW}$, [34]. However, the company is not going further with production until higher efficiency is achieved, [35] 


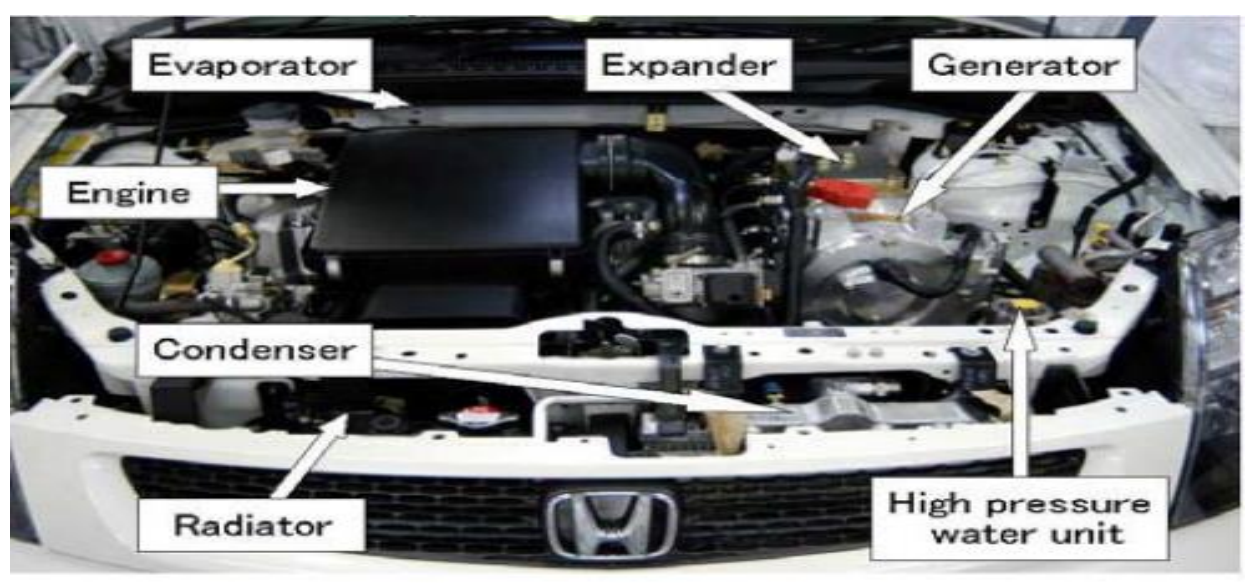

Figure 3.13. Rankine Cycle Prototype Layout, [34].

He et al (2011). proposed a combined ORC and Kalina thermodynamic cycle for WHR to enhance the performance of the Toyota 8A-FE gasoline engine. The steady-state experimental result revealed more exhaust heat recovery with the combined cycle compared to the traditional cycle configuration,[36]. A steady-state test on a TOYOTA 8A-FE gasoline engine working under different conditions has also been published. The performance parameter and power output of the ORC system was measured, and the results showed a thermal efficiency of $14.44 \%,[37]$.

Boretti in 2012 examined the recovery of exhaust and coolant heat in a hybrid passenger car engine with R245fa as working fluid. The findings showed that the fuel efficiency of the exhaust ORC system increased by $3.4 \%$ with a maximum improvement of $6.4 \%$., the coolant ORC presented a maximum fuel efficiency improvement of $2.8 \%$, and the combined system a maximum fuel efficiency of $8.2 \%$ with the engine operating at steady state, [13]. In 2013, Domingues et al. reported a model simulation of the RC for potential exhaust energy recovery from vehicle exhaust gas engines using water, R123 and R245fa as working fluids. It involved both thermodynamic and heat exchanger algorithms to achieve the goal of heat recovery. The study shows an increase of $1.4-3.52 \%$ and $10.16-15.95 \%$ in thermal and mechanical efficiency of ideal heat exchangers using the organic working fluids, respectively,[38]. Kunte and Joerg (2013) explored the suitability of a partially admitted single-stage impulse turbine in the ORC for HD truck and small car applications at three separate operating points. The turbine pulse showed the highest efficiency and allows the use of variable partial admission based on boundary conditions. The possibility to open and close stator passages allows the operation of the turbine at off-design conditions close to the design pressure ratios and maximizes the power output,[39]. 
Tilmann et al (2014). developed an ORC model for predicting waste heat recovery performance and fuel-saving potentials in vehicles which was validated with test rig measurements of the cycle components. The EHR system showed improvement of fuel economy by $3.4 \%$. WHR, therefore, plays an essential role in overcoming the challenges of increased electric power demand in future vehicles,[40]. Daccord et al (2014). developed a piston expander prototype with oil-free hot parts using ethanol as working fluid to determine the effect of various parameters on the performance of the EHR system for passenger cars and heavy commercial vehicles. The built prototype showed promising results, and the expander suits the mobile applications perfectly,[41]. The design of the variable geometry turbine (VGT) of the ORC system model for the recovery of exhaust energy from a 1.251 gasoline engine was proposed by Thaddaeus et al (2016). to assess the benefits of the variable geometry turbine. Results show that VGT increases ORC thermal efficiency and turbine output respectively by $5.6 \%$ and $3.07 \mathrm{~kW}$, [42]. Arise et al. reported the modelling of the ORC system integrated into the engine model in 2016 to evaluate its application opportunities and challenges. System simulations were conducted using different driving conditions, and the results achieved substantial fuel economy improvement with $\mathrm{CO}_{2}$ savings of up to $4 \%$ on standard driving cycles, [43].

Furthermore, Rongqi et al (2016), using the Active Disturbance Rejection Control (ADRC) approach, reported the design of the ORC system for WHR of unstable exhaust heat from automotive engines. The results show that the designed model operates reliably with an evaporative pressure control with an error of less than $0.1 \%$ and a superheating fluctuation of less than $1^{\circ} \mathrm{C}$ compared to the basic ORC system. The additional advantage of the model is that the architecture is simple, since no other thermodynamic cycle or operating fluid is required,[44]. Galindo et al (2017). present a 1D simulation model of an ORC designed with swash-plate expander coupled to $2 \mathrm{~L}$ gasoline engine using ethanol as working fluid. The model demonstrated an expander power output of $800 \mathrm{~W}$, offering a potential $2.5 \%$ improvement of fuel conversion efficiency and a $23.5 \mathrm{~g} / \mathrm{kW}$ reduction in bsfc when operating at $120 \mathrm{~km} / \mathrm{hr}$ NEDC,[45]. Robert et al (2017). studied the economic feasibility of applying the organic Rankin cycle in the transport sector. The study reported a comparison of the maximum permissible mass and the volume of ORC to that of the commercially available ORC product. The results show that for trains, the weight and volume of the ORC must be reduced by $13 \%$ and 59\% respectively. For trucks and buses, the reductions need to be higher,[46].

More so, Amin et al (2017). explored the implementation of WHR on a hybrid electric vehicle under three different driving cycles, including FTP-75, NEDC and US06, to evaluate its 
powertrain benefits. The model simulation resulted in a significant decrease in the overall bsfc of the vehicle,[47]. Zhao et al (2017). designed the ORC recovery system and compared its performance with that of the basic organic Rankine cycle for use in vehicle waste heat recovery. The steady-state results show that the cooling heat decreases with an increase in the net output of the recuperative ORC compared to the basic ORC. According to the report, compared to basic ORC, backpressure and engine performance do not affect recuperative ORC. However, more refrigerant charges and more extended response time are disadvantages,[48]. Yue et al (2019). suggested a method for the harvesting of exhaust energy from vehicles. Model simulation results showed that three efficient ways to increase turbine output power and save fuel are to reduce the LMTD in the evaporator, lower the ambient temperature and increase vehicle speed. The maximum power yield and fuel-saving rate of the model are $14.8 \mathrm{~kW}$ and 0.23 , respectively under the working conditions of the model,[49]. Yang et al (2019). reported a thermo-economic review of the implementation of the ORC system for on-road waste heat recovery vehicles. The study showed the potential for the application of waste heat recovery technology in vehicle engines and the need for cost assessment of the integration of this technology into on-road vehicles,[50].

\subsubsection{Applications in Trucks}

Cars, light-duty vehicles, and motorcycles account for nearly $60 \%$ of GHGs release from the transport sector (Figure 3.14). Medium to heavy-duty trucks contribute $24 \%$ of greenhouse gas emissions, which equates to around $6 \%$ of overall U.S. GHG emissions. It is evident from figure 2.4 that the trucking sector emits a total of $41 \%$ of air pollutions from the transport sector in the United States. Therefore, a possibility exists for the trucking industry within the sustainability movement. The public sector also can support sustainability goals that lead to improvement of technology and road conditions through funding for R\&D programmes, financial incentives, good regulatory practises, and investment in infrastructure. 


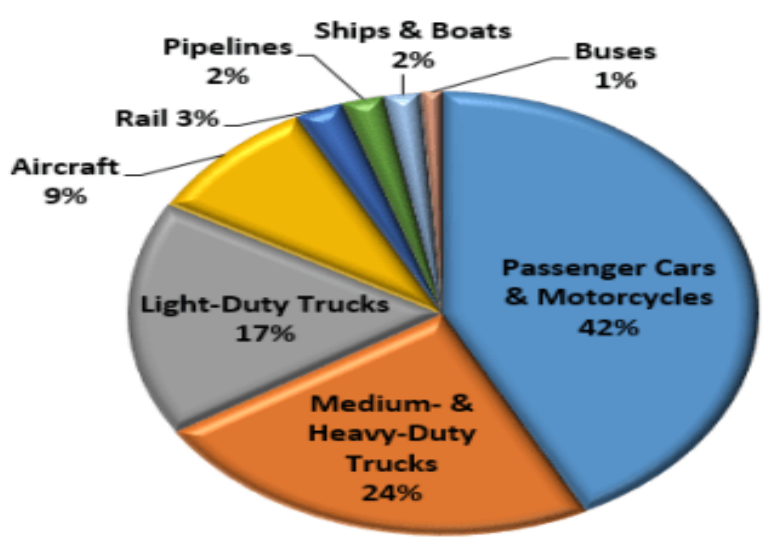

Figure 3.14. US GHG Emissions in the Transportation Sector, [29]

Some recently reported works in applying ORC for exhaust recovery in heavy-duty diesel engines are also reviewed. Teng et al (2017). researched on an ORC method for EHR in heavyduty engines using a highly pressurized dry working fluid. Results showed that the WHR system could achieve up to $20 \%$ increase in engine power without increased fuel consumption and an ORC output of 18\% improvement,[51]. Teng, (2010) reported a study on WHR of heavy-duty engines in a view to reduce emission and cost of operation. The outcome demonstrated ethanol as a right candidate working fluid for use in the Rankine cycle model because of low vapour pressure which in turn makes it relatively cheaper as compared to R245fa mostly used in ORC, [52]. Yu et al (2013). developed a model based on a diesel engine's ORC bottoming method with R245fa as working fluid; the system was formulated to recover energy from the exhaust gas and water jacket. Under the designed conditions, ORC output resulted in an expansion capacity of $14.5 \mathrm{~kW}$, a recovery efficiency of $9.2 \%$ and an exergy efficiency of $21.7 \%$. When combined with bottom ORC, the diesel engine's thermal system output can exceed $6.1 \%,[53]$.

Again, Lang et al (2013). examined the feasibility of WHR from a HD truck engine based on ORC turbo-generator system with siloxane as working fluid. The simulated result gave an addition of $9.6 \mathrm{~kW}$ at $150 \mathrm{~kW}$ engine power output and 1500rpm design point, [54]. Fubin et al (2014). developed a dual-loop Organic Ranking Cycle (ORC) model for the reuse of exhaust energy in a diesel engine using R245fa as a working fluid for both loops. Under the operating conditions, the tests showed a maximum system output of 5.4\%. The system's net power output was $27.85 \mathrm{~kW}$, resulting in a $13 \%$ thermal efficiency increase and a $4 \%$ rise in bsfc,[55]. In 2014, Eaton Corporation reported an approximately 6\% bsfc improvement demonstrated by a root-based expander organic Rankine cycle model testing for WHR from a 13,5L John Deere 
Diesel engine using ethanol and water mixture as working. A project financed by US Department of Energy,[56].

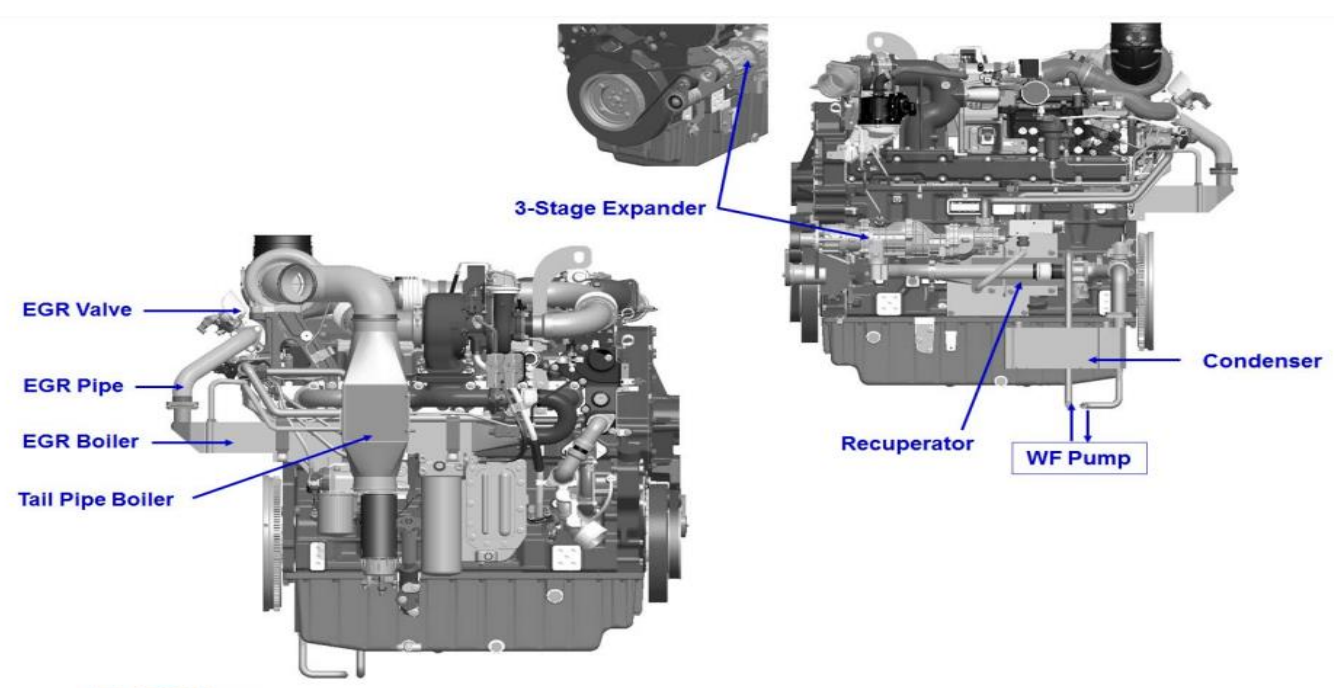

Figure 3.15. Eaton Corporation ORC Model

Amiacabile et al (2015). presented a study on the recovery potentials of EGR using ethanol, pentane and R245fa as candidate working fluids for four different ORC model layouts. Best performance was the result of a subcritical regenerative cycle with ethanol as a working fluid giving $3.3 \%$ bsfc improvement while the minimum cost of capital was from the sub-critical cycle without the recuperator using ethanol as working fluid,[57].

Pooja and Farkade (2016) carried out an experimental test on a single-cylinder, 4-stroke engine to evaluate the available exergy in the exhaust gas of a diesel engine using a shell and tube heat exchanger with water as a working fluid. In their study, they concluded that exhaust energy harvest from diesel engines could increase system performance, save energy, and reduce toxic emissions per kilowatt power generation, [58]. Also, Vijay et al (2016). reported the idea of rehabilitating diesel exhaust heat by adding a thermal transmitter to the exhaust manifold to use the exhaust gas energy for fuel preheating. For a concentrated tube heat exchanger of $130^{\circ} \mathrm{C}$ with $25 \%$ full load and 1500rpm, the output was an increased petrol temperature. The shell and tube evaporator respectively achieved $73 \%$ and $90 \%$ of fuel temperature for parallel and counterflow temperatures at $50 \%$ load and $1500 \mathrm{rpm}$ conditions. In parallel and counterflow systems, the performance of the heat exchanger was set at $75 \%$ and $81 \%$ respectively. The result ultimately concluded that the pre-heating of biodiesel fuel is beneficial,[59].

Elio et al (2017). investigated the recovery of exhaust heat from truck diesel engines using R245fa, R245ca, R134a, R11, R113 and Novec649 as working fluids in the ORC. The model 
analyses aimed to evaluate the optimal efficiency of the process. The study resulted in R11 and R113 as the appropriate working fluids for the ORC model, [60]. Roberto et al (2017). also explored the influence of organic working fluids on the weight and space requisites of ORC applications for EHR in truck engines. The ORC system modelled with 17 working fluids demonstrated that acetone and ethanol harvested more power while isobutane had the highest power-to-weight and power-to-volume ratios of $234 \mathrm{~W} / \mathrm{kg}$ and $277 \mathrm{~W} / \mathrm{dm}^{3}$, respectively, [61]. Anh's (2018) reported a brief review of the application of ORC technology as a WHR system for diesel engines and operating fluids suitable for use as the organic working fluid,[62].

In 2019 Volkswagen and MAN integrated the WHR system into two conventional production vehicles: Golf 7, 2-1 TFSI EA888 and Demo truck D2676 LF25 Euro VI, respectively. The prototypes showed a $75 \%$ evaporator efficiency and a corresponding $3 \%$ reduction in fuel consumption. The research group is now on the lookout for a measure to increase the potential of the WHR system employing an arrangement for the combined electrical/mechanical use of expander power, [63].

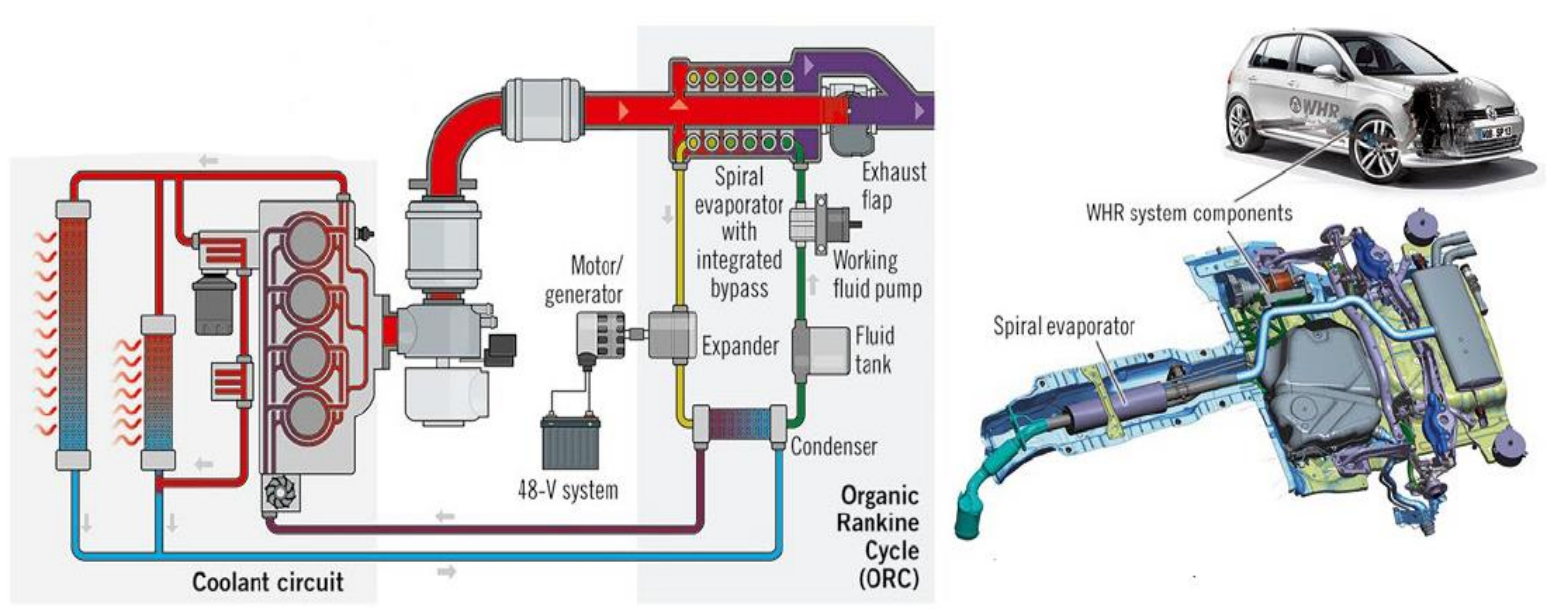

Figure 3.16. WHR System Integration to Volkswagen, [63] 


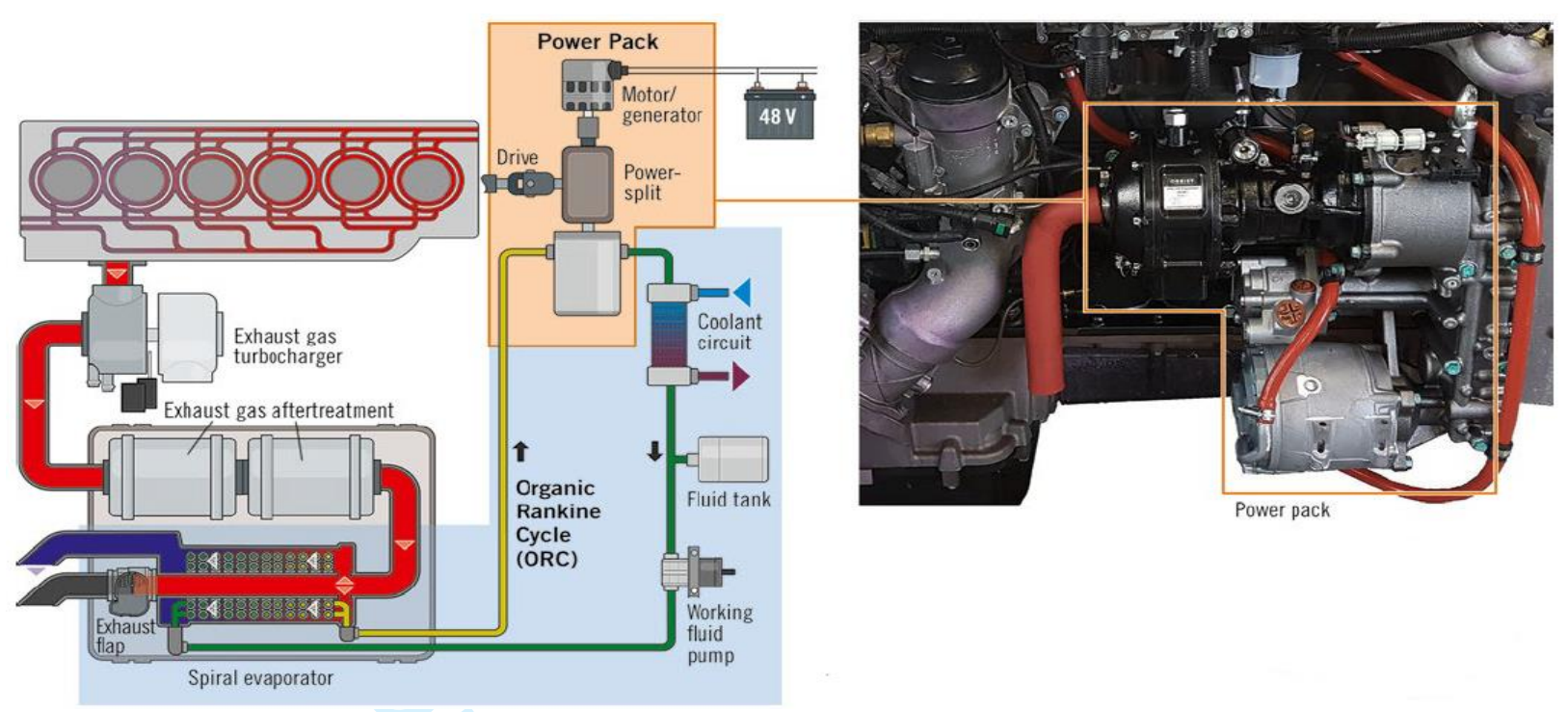

Figure 3.17. WHR System Integration to MAN Truck, [63]

Table 3.2. Summary of Prototypes by Vehicle Manufacturers

\begin{tabular}{|c|c|c|c|c|c|c|c|}
\hline Ref. & Year & Manuf. & Vehicle & Layout & Expander & W. Fluid & Result \\
\hline [30] & 2005 & BMW $1^{\text {st }}$ Gen. & 3 Series & $\begin{array}{l}\text { Dual loop } \\
\text { RC }\end{array}$ & $\begin{array}{l}\text { Vane } \\
\text { Expander }\end{array}$ & $\begin{array}{l}\text { Water \& } \\
\text { Ethanol }\end{array}$ & $5.7 \% \mathrm{\eta}_{t h}$ \\
\hline$[32]$ & 2005 & Cummins & Class 8 & $\begin{array}{l}\text { RC with } \\
\text { Recuperate }\end{array}$ & Turbine & Water & $6 \% \eta_{o r c}$ \\
\hline [34] & 2008 & Honda & HEV & Basic RC & $\begin{array}{l}\text { Axial } \\
\text { Piston }\end{array}$ & Water & $3.8 \% \eta_{t h}$ \\
\hline [31] & 2012 & BMW $2^{\text {nd }}$ Gen. & 5 Series & Basic RC & $\begin{array}{l}\text { Impulse } \\
\text { Turbine }\end{array}$ & Water & $\begin{array}{l}6 \% \\
\eta_{\text {mech }}\end{array}$ \\
\hline$[33]$ & 2013 & Cummings & Class 8 & $\begin{array}{l}\text { RC with } \\
\text { Recuperate }\end{array}$ & Turbine & Water & $55 \% \mathrm{BTE}$ \\
\hline [56] & 2014 & Eaton Corp. & $\begin{array}{l}\text { John Deere } \\
\text { Diesel }\end{array}$ & $\begin{array}{l}\text { Basic } \\
\text { ORC }\end{array}$ & $\begin{array}{l}\text { Root } \\
\text { Expander }\end{array}$ & $\begin{array}{l}\text { Water \& } \\
\text { Ethanol }\end{array}$ & $6 \%$ bsfc \\
\hline$[63]$ & 2019 & Volkswagen & Golf 7 & ORC & $\begin{array}{l}\text { Axial } \\
\text { Piston }\end{array}$ & Ethanol & $5-6 \mathrm{~kW}$ \\
\hline$[63]$ & 2019 & MAN trucks & $\begin{array}{l}\text { D2676 LF25 } \\
\text { Euro VI }\end{array}$ & ORC & $\begin{array}{l}\text { Axial } \\
\text { Piston }\end{array}$ & Ethanol & $4 \%$ bsfc \\
\hline
\end{tabular}




\subsubsection{Vehicle Integration Bottleneck}

The integration of ORC system onto an existing vehicle architecture for recovering exhaust heat demands a balance between the system sophistication, costs, weight. The influence of the additional ORC system on the existing components is more crucial than maximizing the power output; thus, a simple, compact ORC system is appropriate for vehicle integration. The add-on system may result in the following:

\subsubsection{Increased Vehicle Weight}

Increased vehicle weight (mass) due to additional system components results in more traction effort needed to accelerate the vehicle and increase the rolling resistance of the tyres. This addon weight, however, has less effect on long-haul trucks than it does on small cars.

\subsubsection{Increased Back Pressure}

At increased backpressure, the engine must compress the exhausts to a higher-pressure level, which consumes additional mechanical work. The increased back pressure results in increased engine bsfc, emissions, and exhaust temperature, to mention but a few.

\subsubsection{Additional Cooling Demand}

The condenser heat needs to be removed, thus, increasing the cooling requirement of the automobile. The cooling of the working fluid is achieved by installing a separate air-cooled condenser or by integrating it into the existing engine cooling loop, which requires coolant recirculation at higher speeds and higher cooling air velocities.

\subsubsection{Package Consideration}

The ORC system for automotive applications is deployed downstream of the exhaust catalyst so as not to affect emission control. For the integration of the ORC system to be feasible for application in the vehicle, the ORC layout should remain as simple as possible and use existing components in the vehicle to reduce added weight, costs, and intricacy of the system.

\section{Conclusion}

This review presents descriptions of recent developments and researches performed in the deployment of ORC for exhaust exergy recovery system in long-haul truck engines, as reported in published journal articles. The work includes a review of ORC technology, its applications to passenger car and truck engines, and some bottlenecks associated with the integration of ORC systems to vehicle for waste heat recovery. 
The outcomes show that ORC applications in trucks for exhaust gas exergy reuse is a promising technology with possibility of large-scale integration and implementation. However, not many reports exist on the dynamic operations of ORC system models for truck applications to forecast possible real-life situations if these models are adopted. More, so, few available papers report the techno-economic aspects of ORC technology in trucks application and the economic benefits of greenhouse gas reduction of implementing the ORC technology.

\section{References}

[1] Judith Greenwald, (2012). Oil Sands up Close. Available Online via: https://www.c2es.org/2012/11/oil-sands-up-close. [Access: 16-Apr-20].

[2] Department of Transport, (2013). Fuel Consumption. Available Online via: https://www.gov.uk/government/statistical-data-sets/energy-and-environment-datatables-env01. [Access: 16-Apr-20].

[3] Thombare, Dhananjay \& Jadhav, Jaipal. (2013). Review on Exhaust Gas Heat Recovery for I.C. Engine. International Journal of Engineering and Innovative Technology (IJEIT). Volume 2.93-100

[4] ERTRAC, 'Future Light and Heavy Duty ICE Powertrain Technologies', Ertrac, pp. 175, 2016. Available Online via: https://www.ertrac.org/uploads/documentsearch/id40/2016-04

05_ICE_roadmap_edited\%20version.pdf [Accessed: 02-Jun-20)

[5] K. Walkowicz, A. Duran, and E. Burton, 'Fleet DNA Project Data.” (2019). National Renewable Energy Laboratory. Available Online via: www.nrel.gov/fleetdna [Accessed: 9-May-20]

[6] John B. Heywood 'Internal combustion engine fundamentals', Choice Reviews Online, vol. 26, no. $02,1988$.

[7] Klaus Töpfer, 'Energy Efficiency Guide for Industry in Asia', 2006. Online via: file://C:/Users/user/Downloads/Energy\%20Efficiency\%20Guide\%20for\%20Industry \%20in\%20Asia-2006634\%20(1).pdf. [Access: 03-May-20]. 
[8] J.P. Roy, M.K. Mishra, Ashok Misra, Performance analysis of an Organic Rankine Cycle with superheating under different heat source temperature conditions, Applied Energy,Volume 88, Issue 9, 2011, Pages 2995-3004, ISSN 0306-2619, https://doi.org/10.1016/j.apenergy.2011.02.042.

[9] Gang Pei, Jing Li, Yunzhu Li, Dongyue Wang, Jie Ji, Construction and dynamic test of a small-scale organic rankine cycle, Energy, Volume 36, Issue 5, 2011, Pages 32153223, ISSN 0360-5442, https://doi.org/10.1016/j.energy.2011.03.010.

[10] Hou, Guolian, Shanshan Bi, Mingming Lin, Jianhua Zhang, and Jinliang Xu. "Minimum variance control of organic Rankine cycle-based waste heat recovery." Energy Conversion and Management 86 (2014): 576-586.

[11] Shedid Mohamed and Moses Sashi Kumar, 'Review on Exhaust Heat Recovery Systems in Diesel Engine', Int. J. Adv. Eng. Res. Sci., vol. 4, no. 11, pp. 91-97, 2017.

[12] Iacopo Vaja, Agostino Gambarotta, Internal Combustion Engine (ICE) bottoming with Organic Rankine Cycles (ORCs), Energy, Volume 35, Issue 2, 2010, Pages 1084-1093, ISSN 0360-5442, https://doi.org/10.1016/j.energy.2009.06.001.

[13] Alberto Boretti, Recovery of exhaust and coolant heat with R245fa organic Rankine cycles in a hybrid passenger car with a naturally aspirated gasoline engine, Applied Thermal Engineering, Volume 36, 2012, Pages 73-77, ISSN 1359-4311, https://doi.org/10.1016/j.applthermaleng.2011.11.060.

[14] Arias, Diego \& Shedd, Tim \& Jester, Ryan. (2006). Theoretical Analysis of Waste Heat Recovery from an Internal Combustion Engine in a Hybrid Vehicle. 10.4271/2006-011605.

[15] Jian Song, Chun-wei Gu, Parametric analysis of a dual loop Organic Rankine Cycle (ORC) system for engine waste heat recovery, Energy Conversion and Management, Volume 105, 2015, Pages 995-1005, ISSN 0196-8904, https://doi.org/10.1016/j.enconman.2015.08.074.

[16] Oomori, H. and Ogino, S., "Waste Heat Recovery of Passenger Car Using a Combination of Rankine Bottoming Cycle and Evaporative Engine Cooling System," SAE Technical Paper 930880, 1993, https://doi.org/10.4271/930880. 
[17] Engineering ToolBox, (2003). Refrigerants - Environmental Properties. [online] Available at: https://www.engineeringtoolbox.com/refrigerants-properties-d_145.html [Accessed: 01-06-20].

[18] Engineering ToolBox, (2005). Refrigerants - Physical Properties. [online] Available at: https://www.engineeringtoolbox.com/refrigerants-d_902.html [Accessed: 01-06-20].

[19] M. Erbaş and A. Biyikoglu, "Design of low temperature Organic Rankine Cycle and turbine," 4th International Conference on Power Engineering, Energy and Electrical Drives, Istanbul, 2013, pp. 1065-1070, doi: 10.1109/PowerEng.2013.6635758.

[20] Huijuan Chen, D. Yogi Goswami, Elias K. Stefanakos, A review of thermodynamic cycles and working fluids for the conversion of low-grade heat, Renewable and Sustainable Energy Reviews, Volume 14, Issue 9, 2010, Pages 3059-3067, ISSN 13640321, https://doi.org/10.1016/j.rser.2010.07.006.

[21] NFPA 704 Standard System for the Identification of the Hazards of Materials for Emergency Response - 2012 Edition. Via: https://www.grainger.com/content/qt-nfpa704-304

[22] NFPA Hazard Rating Information for Common Chemicals. Available Online via: https://www.northeastern.edu/ehs/ehs-programs/laboratory-safety/generalinformation/nfpa-hazard-rating-system/[Accessed: 01-Jun-20)

[23] List of refrigerants. Available Online via: https://en.wikipedia.org/wiki/List_of_refrigerants [Accessed: 01-Jun-20].

[24] Jacopo Vivian, Giovanni Manente, Andrea Lazzaretto, A general framework to select working fluid and configuration of ORCs for low-to-medium temperature heat sources,Applied Energy, Volume 156, 2015, Pages 727-746, ISSN 0306-2619, https://doi.org/10.1016/j.apenergy.2015.07.005.

[25] Xuan Wang, Gequn Shu, Hua Tian, Peng Liu, Xiaoya Li, Dongzhan Jing, Dynamic Response Performance Comparison of Ranking Cycles with Different Working Fluids for Waste Heat Recovery of Internal Combustion Engines, Energy Procedia, Volume 105, 2017, Pages 1600-1605, ISSN 1876-6102, https://doi.org/10.1016/j.egypro.2017.03.512.

[26] Hua Tian, Gequn Shu, Haiqiao Wei, Xingyu Liang, Lina Liu, Fluids and parameters optimization for the organic Rankine cycles (ORCs) used in exhaust heat recovery of Internal Combustion Engine (ICE), Energy, Volume 47, Issue 1, 2012, Pages 125-136, 
ISSN 0360-5442, https://doi.org/10.1016/j.energy.2012.09.021.

[27] Bahaa Saleh, Gerald Koglbauer, Martin Wendland, Johann Fischer, Working fluids for low-temperature organic Rankine cycles, Energy, Volume 32, Issue 7, 2007, Pages 1210-1221, ISSN 0360-5442, https://doi.org/10.1016/j.energy.2006.07.001.

[28] White, Martin. "The design and analysis of radial inflow turbines implemented within low temperature organic Rankine cycles." PhD thesis, City University London, 2015.

[29] American Transportation Research Institute (ATRI), US Greenhouse Gas Emissions in the Transportation Sector. Available Online via: http://truckingresearch.org/sustainabletrucking-and-the-environment/\# ftnref3 [Access:16-Apr-20]

[30] Freymann, Prof \& Strobl, Dipl.-Ing \& Obieglo, Dr. (2008). The turbo-steamer: A system introducing the principle of cogeneration in automotive applications. MTZ worldwide. 69. 20-27. 10.1007/BF03226909.

[31] Freymann, R., Ringler, J., Seifert, M. et al. The Second-Generation Turbosteamer. MTZ Worldwide 73, 18-23 (2012). https://doi.org/10.1365/s38313-012-0138$\underline{1}$

[32] Christopher Nelson, Exhaust Energy Recovery. In: Diesel Engine Efficiency and Emissions Research (DEER) Conference. Dearborn, MI. August 2008. Available Online via: https://www.energy.gov/sites/prod/files/2014/03/f8/deer08 nelson.pdf [Access: 16-Apr20].

[33] David Koeberlein, Cummins SuperTruck Program Technology and System Level Demonstration of Highly Efficient and Clean, Diesel Powered Class 8 Trucks. Presentation at US Department of Energy, Merit Review, 2013. Available Online via: https://www.energy.gov/sites/prod/files/2014/03/f13/ace057_koeberlein_2013_o.pdf [Access: 16-Apr-20].

[34] Endo, T., Kawajiri, S., Kojima, Y., Takahashi, K., Baba, T., Ibaraki, S., Shinohara, M. (2007). Study on Maximizing Exergy in Automotive Engines. SAE Technical Paper Series. doi:10.4271/2007-01-0257

[35] J. Rosebro, 'Honda Researching Advanced Hybrid Drive with Rankine Cycle Co-Generation', no. $\quad$ February Available Online via: https://www.greencarcongress.com/2008/02/honda-researchi/comments/ [Access: 27-Apr- 
20]

[36] Maogang He, Xinxin Zhang, Ke Zeng, Ke Gao, A combined thermodynamic cycle used for waste heat recovery of internal combustion engine, Energy, Volume 36, Issue 12, 2011, Pages 6821-6829, ISSN 0360-5442, https://doi.org/10.1016/j.energy.2011.10.014

[37] Zhang, Xinxin \& ZENG, Ke \& BAI, Sujuan \& Zhang, Ying \& He, Maogang. Exhaust Recovery of Vehicle Gasoline Engine Based on Organic Rankine Cycle. SAE 2011 World Congress and Exhibition. 10.4271/2011-01-1339.

[38] António Domingues, Helder Santos, Mário Costa, Analysis of vehicle exhaust waste heat recovery potential using a Rankine cycle, Energy, Volume 49, 2013, Pages 71-85, ISSN 0360-5442, https://doi.org/10.1016/j.energy.2012.11.001.

[39] Kunte, Harald \& Seume, Joerg. (2013). Partial Admission Impulse Turbine for Automotive ORC Application. 6. 10.4271/2013-24-0092.

[40] Tilmann Abbe Horst, Wilhelm Tegethoff, Peter Eilts, Juergen Koehler, Prediction of dynamic Rankine Cycle waste heat recovery performance and fuel saving potential in passenger car applications considering interactions with vehicles' energy management, Energy Conversion and Management, Volume 78, 2014, Pages 438-451, ISSN 01968904, https://doi.org/10.1016/j.enconman.2013.10.074

[41] Daccord, R., Darmedru, A., and Melis, J., "Oil-Free Axial Piston Expander for Waste Heat Recovery," SAE Technical Paper 2014-01-0675, 2014, https://doi.org/10.4271/2014-01-0675

[42] Thaddaeus, Julius, Apostolos Pesiridis, and Apostolos Karvountzis-Kontakiotis. "Design of variable geometry waste heat recovery turbine for high efficiency internal combustion engine." Int. J. Sci. Eng. Res 7 (2016): 1001-1017.

[43] Arsie, Ivan \& Cricchio, Andrea \& Pianese, Cesare \& Ricciardi, Vincenzo \& De Cesare, Matteo, "Modelling and Optimization of Organic Rankine Cycle for Waste Heat Recovery in Automotive Engines," SAE Technical Paper 2016-01-0207, 2016, https://doi.org/10.4271/2016-010207

[44] Rongqi Shi, Tianqi He, Jie Peng, Yangjun Zhang, Weilin Zhuge, System design and control for waste heat recovery of automotive engines based on Organic Rankine Cycle, Energy, Volume 102, 2016, Pages 276-286, ISSN 0360-5442, 


\section{https://doi.org/10.1016/j.energy.2016.02.065}

[45] José Galindo, Vicente Dolz, Lucía Royo-Pascual, Aldrik Brizard, Dynamic Modeling of an Organic Rankine Cycle to recover Waste Heat for transportation vehicles, Energy Procedia, Volume 129, 2017, Pages 192-199, ISSN 1876-6102, https://doi.org/10.1016/j.egypro.2017.09.111

[46] Roberto Pili, Alessandro Romagnoli, Hartmut Spliethoff, Christoph Wieland, Economic Feasibility of Organic Rankine Cycles (ORC) in Different Transportation Sectors, Energy Procedia, Volume 105, 2017, Pages 1401-1407, ISSN 1876-6102, https://doi.org/10.1016/j.egypro.2017.03.521.

[47] Mahmoudzadeh Andwari, Amin, Pesyridis, Apostolos, Karvountzis, Apostolos and Esfahanian, Vahid. (2017). Hybrid Electric Vehicle Performance with Organic Rankine Cycle Waste Heat Recovery System. Applied Sciences. 7. 437. 10.3390/app7050437.

[48] Mingru Zhao, Gequn Shu, Hua Tian, Fengying Yan, Guangdai Huang, Chen Hu, The investigation of the Recuperative Organic Rankine Cycle models for the waste heat recovery on vehicles, Energy Procedia, Volume 129, 2017, Pages 732-739, ISSN 18766102, https://doi.org/10.1016/j.egypro.2017.09.106.

[49] Chen Yue, Pengen Wang, Thermal analysis on vehicle energy supplying system based on waste heat recovery ORC, Energy Procedia, Volume 158, 2019, Pages 5587-5595, ISSN 1876-6102, https://doi.org/10.1016/j.egypro.2019.01.582

[50] Yang, Jingye \& Yu, Binbin \& Lu, Bingqing \& Chen, Jiangping. (2019). Thermoeconomic review of micro-scale organic Rankine cycle integrated into vehicle engines for waste heat recovery. 10.11322/tjsrae.18-35AC_OA

[51] Teng, H., Regner, G., and Cowland, C., "Waste Heat Recovery of Heavy-Duty Diesel Engines by Organic Rankine Cycle Part I: Hybrid Energy System of Diesel and Rankine Engines," SAE Technical Paper 2007-01-0537, 2007, https://doi.org/10.4271/2007-01$\underline{0537 .}$.

[52] Teng, Ho. (2010). Waste Heat Recovery Concept to Reduce Fuel Consumption and Heat Rejection from a Diesel Engine. SAE International Journal of Commercial Vehicles. 3. 60-68. 10.4271/2010-01-1928.

[53] Guopeng Yu, Gequn Shu, Hua Tian, Haiqiao Wei, Lina Liu, Simulation and 
thermodynamic analysis of a bottoming Organic Rankine Cycle (ORC) of diesel engine (DE), Energy, Volume 51, 2013, Pages 281-290, ISSN 0360-5442, https://doi.org/10.1016/j.energy.2012.10.054.

[54] Lang, Wolfgang \& Colonna, Piero \& Almbauer, Raimund. (2013). Assessment of Waste Heat Recovery from a Heavy-Duty Truck Engine by Means of an ORC Turbogenerator. Journal of Engineering for Gas Turbines and Power. 135. 042313. 10.1115/1.4023123.

[55] Fubin Yang, Xiaorui Dong, Hongguang Zhang, Zhen Wang, Kai Yang, Jian Zhang, Enhua Wang, Hao Liu, Guangyao Zhao, Performance analysis of waste heat recovery with a dual loop organic Rankine cycle (ORC) system for diesel engine under various operating conditions, Energy Conversion and Management, Volume 80, 2014, Pages 243-255, ISSN 0196-8904, https://doi.org/10.1016/j.enconman.2014.01.036.

[56] Swami Nathan Subramanian, 'Vehicle Technologies Program Review', Eaton Corporation, 2014. Available Online via: https://www.energy.gov/sites/prod/files/2014/07/f17/ace088_subramanian_2014_o.pdf [ Accessed: 26-Apr-20]

[57] Simone Amicabile, Jeong-Ik Lee, Dongsuk Kum, A comprehensive design methodology of organic Rankine cycles for the waste heat recovery of automotive heavy-duty diesel engines, Applied Thermal Engineering, Volume 87, 2015, Pages 574-585, ISSN 13594311, https://doi.org/10.1016/j.applthermaleng.2015.04.034.

[58] Pooja B. Surwase and H. S. Farkade, 'Waste heat recovery from the exhaust of a diesel engine using parallel flow shell and tube heat exchanger', International Journal of Mechanical And Production Engineering, ISSN: 2320-2092, Volume- 4, Issue-6, Jun.2016 pp. 150-153.

[59] Vijay V. S., Aravinda Bhat K., Sachin Shetty, Gurudatta N. V., Russell Sequeira, Design and Fabrication of Heat Exchanger for Waste Heat Recovery from Exhaust Gas of Diesel Engine, Journal of Mechanical Engineering and Automation, Vol. 6 No. 5A, 2016, pp. 131-137. doi: 10.5923/c.jmea.201601.25

[60] Elio Antonio Bufi, Sergio Mario Camporeale, Paola Cinnella, Robust optimization of an Organic Rankine Cycle for heavy duty engine waste heat recovery, Energy Procedia, Volume 129, 2017, Pages 66-73, ISSN 1876-6102, 


\section{https://doi.org/10.1016/j.egypro.2017.09.190.}

[61] Roberto Pili, Jesus D. Castro Pastrana, Alessandro Romagnoli, Hartmut Spliethoff, Christoph Wieland, Working Fluid Selection and Optimal Power-to Weight Ratio for ORC in Long-Haul Trucks, Energy Procedia, Volume 129, 2017, Pages 754-761, ISSN 1876-6102, https://doi.org/10.1016/j.egypro.2017.09.116.

[62] Anh Tuan Hoang, Waste heat recovery from diesel engines based on Organic Rankine Cycle, Applied Energy, Volume 231, 2018, Pages 138-166, ISSN 0306-2619, https://doi.org/10.1016/j.apenergy.2018.09.022.

[63] Carstensen, A., Horn, A., Klammer, J. et al. Waste Heat Recovery in Passenger Cars and Trucks. MTZ Worldw 80, 50-57 (2019). https://doi.org/10.1007/s38313-019-00143 